\title{
Oligocene ruminants from the Kızılırmak Formation, Çankırı-Çorum Basin, Central Anatolia, Turkey
}

\author{
Grégoire Métais, Ebru Albayrak, Pierre-Olivier Antoine, Ozan Erdal, \\ Levent Karadenizli, Neşe Oyal, Gerçek Saraç, Yeşim Büyükmeriç, and Sevket Sen
}

\begin{abstract}
A new assemblage of ruminants from five distinct Oligocene localities of the Kızılırmak Formation, Central Anatolia, Turkey is described. The tragulids Iberomeryx parvus, and Iberomeryx sp. (large), as well as a probable large lophiomerycid have been recognized. The stem pecoran Dremotherium guthi, cf. Palaeohypsodontus and a large indeterminate Pecora have been identified as well. In the five localities, the majority of the ruminant material is referred to Iberomeryx parvus, but the sample from the locality Tepe 641 (upper member of the Kızılırmak Formation) shows some distinctive characters suggesting a more derived species/forms that probably lived in more open environments. The ruminant taxa recorded in the Kızılırmak Formation are congruent with a late Oligocene age, probably close in age to the Benara fauna of southern Georgia. The possible occurrence of Palaeohypsodontus in Central Anatolia would significantly expand its geographical range and suggest biogeographical affinities with Central Asia. The ruminant fauna from the Kızılırmak Formation suggests the existence of lowland forests with more open landscapes in central Anatolia during the late Oligocene.
\end{abstract}

Grégoire Métais. Sorbonne Universités, CR2P, MNHN, CNRS, UPMC, Muséum National d'Histoire Naturelle, 57 rue Cuvier, CP 38, 75005 Paris, France. metais@mnhn.fr.

Ebru Albayrak. Natural History Museum, Maden ve Tektik Arama Genel Müdürlügü, 06520 Ankara, Turkey, ebrualbayrak@gmail.com

Pierre-Olivier Antoine. ISEM, Université de Montpellier, CNRS, IRD, EPHE, CC64, Place Eugène

Bataillon, F-34095 Montpellier, France, Pierre-Olivier.Antoine@isem.univ-montp2.fr

Ozan Erdal. Istanbul Technical University, Eurasia Institute of Earth Sciences, 34469 Maslak-Istanbul,

Turkey, erdalo@itu.edu.tr

Levent Karadenizli. Geology Department, Maden ve Tektik Arama Genel Müdürlügü, 06520 Ankara,

Turkey, levent.karadenizli@gmail.com

Neşe Oyal. Natural History Museum, Maden ve Tektik Arama Genel Müdürlügü, 06520 Ankara, Turkey, neseoyal@hotmail.com

Gerçek Saraç. Natural History Museum, Maden ve Tektik Arama Genel Müdürlügü, 06520 Ankara, Turkey, gerceksarac@hotmail.com

Métais, Grégoire, Albayrak, Ebru, Antoine, Pierre-Olivier, Erdal, Ozan, Karadenizli, Levent, Oyal, Neşe, Saraç, Gerçek, Büyükmeriç, Yeşim, and Sen, Sevket. 2016. Oligocene ruminants from the Kızılırmak Formation, Çankırı-Çorum Basin, Central Anatolia, Turkey. Palaeontologia Electronica 19.3.37A: 1-23

palaeo-electronica.org/content/2016/1619-oligocene-ruminant-from-turkey

Copyright: @ October 2016 Society of Vertebrate Paleontology. This is an open access article distributed under the terms of the Creative Commons Attribution License, which permits unrestricted use, distribution, and reproduction in any medium, provided the original author and source are credited.

creativecommons.org/licenses/by/4.0/ 
Yeşim Büyükmeriç. Geological Engineering Department, Bülent Ecevit Üniversitesi, İncivez-Zonguldak, 67100 Zonguldak, Turkey, yesimbuyukmeric@beun.edu.tr

Sevket Sen. Sorbonne Universités, CR2P, MNHN, CNRS, UPMC, Muséum National d'Histoire Naturelle, 57 rue Cuvier, CP 38, 75005 Paris, France, sen@mnhn.fr

Keywords: Ruminantia; Oligocene; traguloids; Pecora; Kızılırmak Formation; Turkey

Submission: 15 January 2016 Acceptance: 22 August 2016

\section{INTRODUCTION}

The Oligocene fossil record of ruminants in Asia Minor is almost unknown. The only reference mammal fauna in the region is that of Benara (Georgia) which has yielded the traguloids Iberomeryx parvus Gabunia 1964 and Lophiomeryx benarensis Gabunia 1964, and the stem pecoran Prodemotherium trepidum Gabunia 1964. The age of the Benara fauna has been subject to different interpretation ranging from early Oligocene (Lucas and Emry, 1999), to late Oligocene (Russell and Zhai, 1987). De Bruijn et al. (2003) support the late Oligocene age on the basis of the stratigraphic relationships between the Vale lignite that yielded the Benara fauna, and the fluvio-lacustrine deposits of Süngülü containing an assemblage of mammalian remains considered to be of latest Eocene or earliest Oligocene age. The late Oligocene Güngörmez Formation (subsequently named Güngören Formation in Varol et al., 2015) exposed in the Kağızman-Tuzluca Basin of Eastern Anatolia has also yielded fragmentary remains of ruminants tentatively referred to Nalameryx sp., a genus known from the Oligocene deposits of Pakistan (Métais et al., 2015).

In Western Europe, the Oligocene ruminants are relatively well documented with different lineages and assemblages through time (Mennecart, 2015), although the stratigraphic ranges of most taxa defined from the karstic sediments of the "phospohrites du Quercy" (France) remains poorly constrained. In Central and eastern Asia, many taxa have been reported from late Eocene-Oligocene strata since the 1920's (i.e., Matthew and Granger, 1924), and most of those forms dispersed into Europe during or after the Grande Coupure (Stehlin, 1909).

Central Anatolia is located at the geographic crossroads of Asia, Africa, and Europe, and therefore constitutes a critical area to understanding mammalian distributions and dispersal histories along and across the Neotethys Ocean during the Cenozoic. Prior to the retreat of the Siberian Sea that preceded the Grande Coupure, Anatolia was certainly part of the hypothetical transcontinental migration route (Böhme et al., 2013), although so far no faunal data from Anatolia can presently substantiate this hypothesis. During the Oligocene, the rodent faunas of Anatolia suggest complex biogeographic pattern with episodic affinities with Europe and Asia, and endemism probably related to isolation (de Bruijn et al., 2003; Ünay et al., 2003; Antoine et al., 2008).

The scope of this paper is to provide a review of the ruminant material currently available from the late Oligocene Kızılırmak Formation of Central Anatolia (Karadenizli, 2011). The Oligocene is an important time slice with regard to the origin of crown ruminants, what is an enigma yet, and the past traguline diversity. While not solving these critical issues, our goal here is to bring new fossil data which, although fragmentary, help understanding the biodiversity and biogeography of late Oligocene ruminants. These forms are generally poorly known and distributed across Eurasia during the late Oligocene-early Miocene, and later in Africa during the early Miocene. The fossil material described herein was collected from five different localities stratigraphically situated in the Kızılırmak Formation (Figure 1). The Kızılırmak Formation is about $120 \mathrm{~m}$ thick in the study area. Although the fossiliferous outcrops are not physically correlatable, one can stratigraphically distinguish the localities (GK 1,2,3) situated near the village of Gözükızıllı, and lying near the contact between the underlying Güvendik Formation from a group of localities (Bağdatı, TP641, Kızılırmak type locality) located about $15 \mathrm{~km}$ to the north and stratigraphically situated in the upper part of the Kızılırmak Formation. The clays and evaporites of the Güvendik Formation pass conformably to the lowermost part of the Kizılırmak Formation (Figures 1, 2). The lowest fossil locality GK-3 is situated $10 \mathrm{~m}$ above the Güvendik-Kizilirmak transition. The following fossiliferous horizon, at $15 \mathrm{~m}$ above this boundary, is GK-2, which has yielded abundant remains of the gigantic rhinocerotoid Paraceratherium sp. and other vertebrates (Antoine et al., 2008). The fossil 


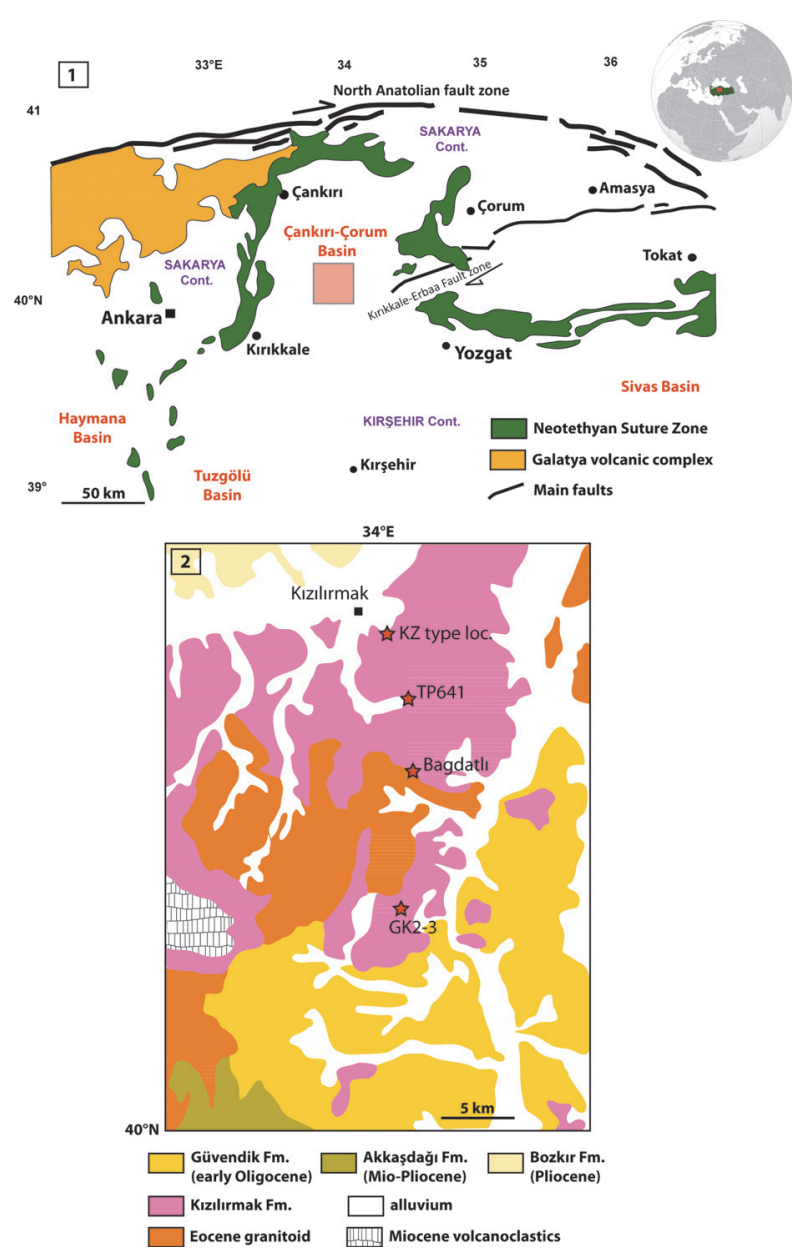

FIGURE 1. Location map of late Oligocene mammal localities and sections from the Kızılırmak Formation (Çankırı-Çorum Basin, north central Anatolia, Turkey). 1, geotectonic map of Central Anatolia showing the basins including the Çankırı-Çorum Basin, and the main structural features of the area; 2, Geological map of the studied area with the four fossil localities of the Kızılırmak Formation discussed in the text.

locality named GK-1 is situated about $50 \mathrm{~m}$ above the Güvendik-Kizilirmak boundary on the Gözükızıllı section (Figure 2). This locality has not produced ruminant material, but Ünay et al., (2003) reported a rodent fauna from there. Paraceratherium is also documented in Bağdatlı. The localities Tepe 641 and Kızılırmak type locality are situated at about $15 \mathrm{~km}$ North of Gözükızıllı (Figure 1), and lie stratigraphically in the upper part of the Kızılırmak Formation. The stratigraphic relationships between the different mammal localities and the lithostratigraphic description of the Kızılırmak Formation are available in Karadenizli (2011). Despite the scarcity of the material, some specimens are diagnostic enough to propose generic identifica- tion, and at least four ruminant genera have been identified.

\section{Geological Setting}

The Çankırı-Çorum Basin is one of the largest Cenozoic basins in Turkey (Figure 1.1). It is bounded to the west, north and east by the Izmir Ankara Erzincan suture zone (IAESZ), which demarcates the former position of the northern branch of the Neotethys, and to the south by the Kırşehir block.

The tectonic evolution of the Central Anatolian basins is extremely complex, and can be summarized as a succession of orogenic collage forming a mosaic of continental blocks separated by ophiolitic suture zones (Görür et al., 1998). This complex structure was formed as a result of the closure of the multi-branched Neotethys Ocean during the Late Cretaceous-Miocene (Şengör and Yılmaz, 1981). The Oligocene is marked by the fusion of different basins into a vast epi-Anatolid molasse basin extending from Ankara to eastern Anatolia with terrestrial infill generally interfingering with evaporites or nearshore marine sediments (Görür et al., 1998). The geological history of the ÇankırıÇorum Basin, like that of the other Central Anatolian basins, started in the Late Cretaceous-early Cenozoic with the closure of the Neotethys Ocean. These basins gained individual characters after the closure of the Neotethys during the Eocene (Şengör and Yılmaz, 1981; Görür et al., 1998). A different sequence in each of the Central Anatolian sedimentary basins resulted from a complex movement history between the Sakarya and Kırşehir blocks (Şengör and Yılmaz, 1981; Görür et al., 1984). Due to increasing intensity of tectonism, marine realms in Central Anatolia decayed since Eocene times, and nearly came to end by the early Neogene, except for some small areas in eastern and southeastern Turkey (Koçyiğit, 1991; Görür et al., 1998).

The Çankırı-Çorum Basin is one of the most prominent sedimentary basins in Central Anatolia, and it contains a total of more than $6 \mathrm{~km}$ of sedimentary strata, including thick sequences of fluviolacustrine sediments accumulated mostly during Neogene times (Sen et al., 1998). These continental formations are widely exposed in the ÇankırıÇorum Basin, and have yielded numerous fossil mammal localities ranging in age from Oligocene to Pliocene (Karadenizli, et al., 2004). The continental clastic sediments of the Kızılırmak Formation are widely exposed in the northern part of the Çankırı-Çorum Basin. This lithostratigraphic unit is 


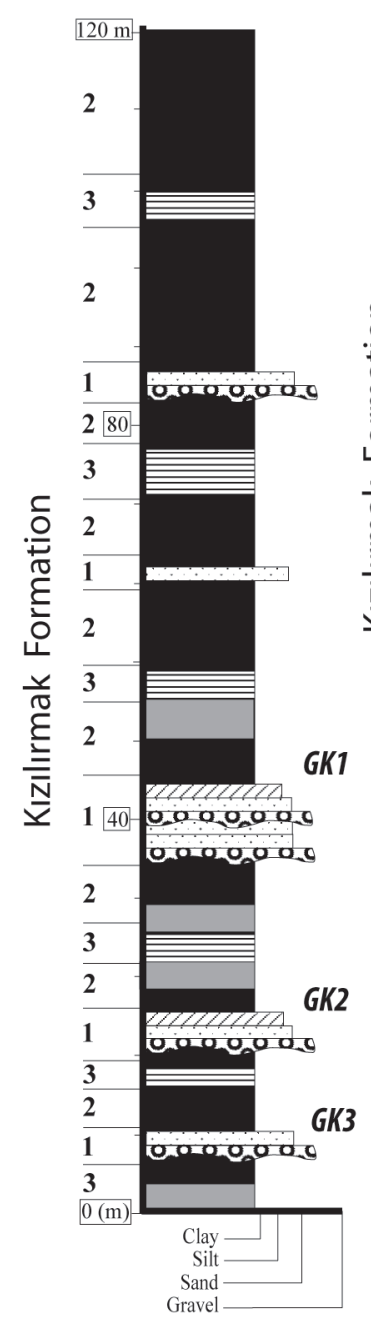

Gözükızıllı section

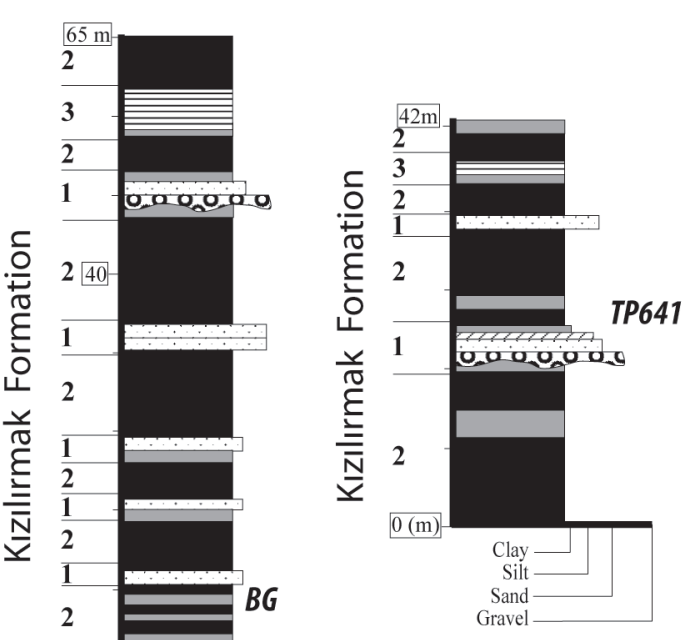

Tepe 641 section

Bagdatlı section
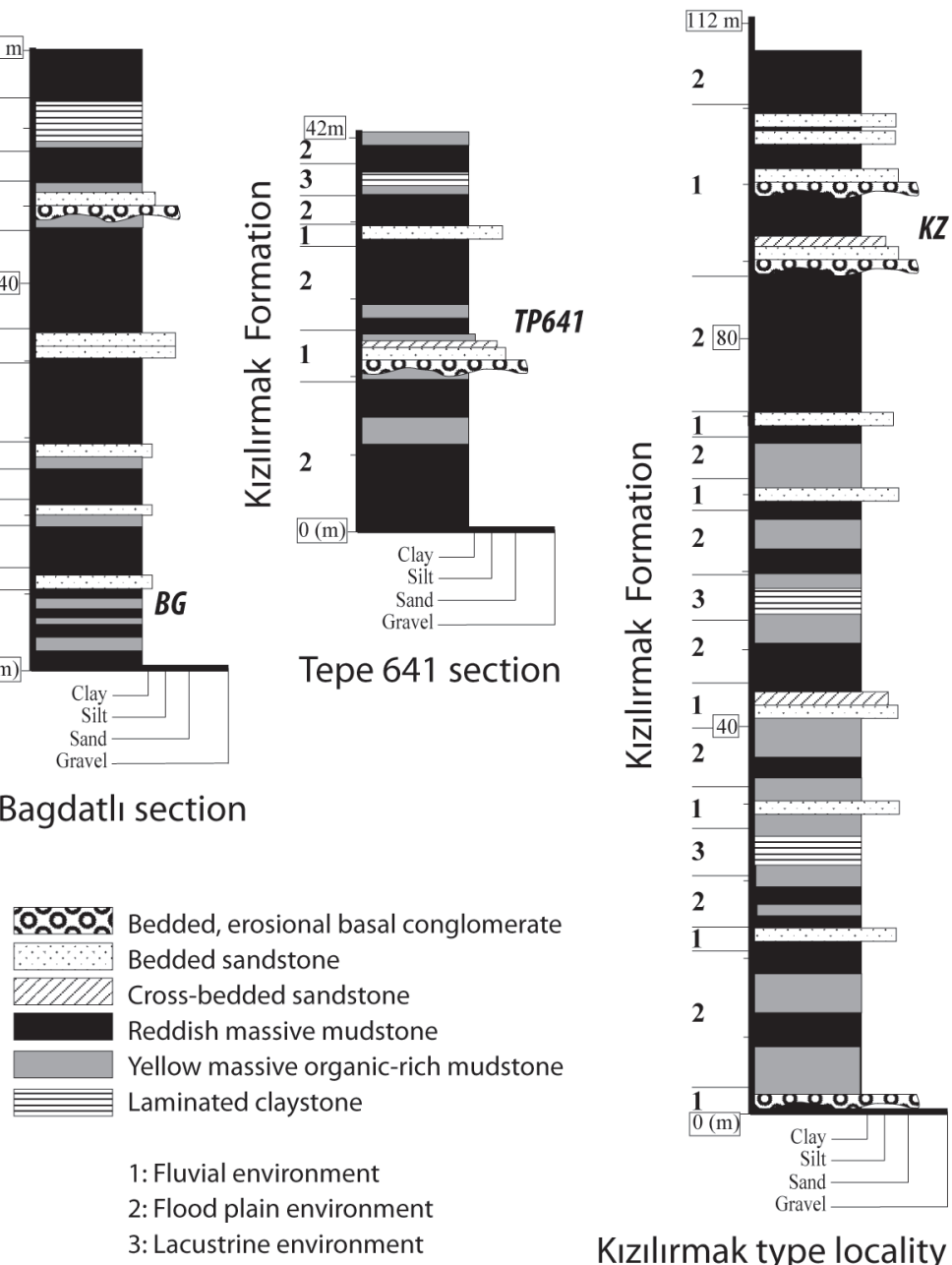

Kızılırmak type locality section

FIGURE 2. The four sampled sections showing the stratigraphic position of fossil localities in the Kızılırmak Formation (modified from Karadenizli et al., 2004).

composed of sandy clays, moderately coarsegrained sandstones with lenses of grey-colored clay, alternating with grey-blue to reddish mudstones suggesting deposition in a vast meandering river system.

The Kızılırmak Formation overlies conformably the early Oligocene Güvendik Formation whereas its upper boundary is unconformably overlain by late Miocene or younger deposits (Karadenizli et al., 2004). The late Oligocene age of the Kızılırmak is based on the mammal fauna it has yielded (Karadenizli, et al., 2004; Antoine et al., 2008, this paper). Its thickness varies from 110 to $120 \mathrm{~m}$. The formation is mainly composed of bedded sandstones, massive mudstones and bedded conglomerates having dominantly red and brown colors. During the late Oligocene, fluvial environmental conditions dominated in the western parts of the basin, whereas deposits of floodplain and shallow lacustrine environments occurred in its centre (Karadenizli, 2011).

\section{MATERIAL AND METHODS}

The new ruminant material described herein was recovered by surface collecting, and by screen-washing of matrix using only water. The quality of preservation of isolated teeth is variable but generally good. A few teeth and most postcranial remains have suffered damage which is ascribed to post-depositional breakage. The enamel surface in at least one tooth is deeply pitted probably from chemical erosion. The dental terminology follows Bärmann and Rössner (2011). Throughout the text, the term M structure (Dorcatherium-fold, Tragulus-fold, or $\Sigma$-structure, 
Figure 3.11) refers to the presence of an interior and exterior postmetacristid, as well as interior and exterior postprotocristid. The used postcranial terminology is mesio/distal, media/lateral, and plantar/ dorsal. The body mass estimations provided from the size of the astragalus follow the method proposed in Martinez and Sudre (1995). The estimated body mass of $I$. parvus from Benara was obtained by using the $\mathrm{m} 1$ area $(\mathrm{Wm} 1)$ of the type specimen (Gabunia, 1964, p. 182) and the method of Legendre (1989). The fossil material described herein belongs to the MTA Museum, Ankara. The acronym used for specimens refers to the locality where they were unearthed. Abbreviations used in the text: the upper premolars and molars are indicated by $P$ or $M$, respectively, lower molars by $m$, lower premolars by $p$, and deciduous teeth are preceded by $\mathrm{d}$ or $\mathrm{D}$. Symbols used for biometric data, L: length; W: width; TD: transverse diameter. Measurements are in millimeters.

\section{SYSTEMATIC PALAEONTOLOGY}

Suborder RUMINANTIA Scopoli, 1777

Family TRAGULIDAE Milne-Edwards, 1864

Genus IBEROMERYX Gabunia, 1964

Type species. Iberomeryx parvus Gabunia, 1964

Iberomeryx parvus Gabunia, 1964

Figures 3.1-3.21, 4.1-4.16

Referred species. I. minor (Filhol, 1882); I. sp. cited in Sudre, 1984).

Referred material. This taxon has been identified in the five localities that yielded ruminant material.

Gözükızıllı 2 (lower member of the Kızılırmak Formation). Rght cubo-navicular (GK2-5), right maxilla with D2-M1 (GK2-4), lower jaw with erupting right $m 2$ (GK2-10), lower jaw with right $d 3$, d4, and the trigonid of $\mathrm{m} 1$ (GK2-11).

Gözükızıllı 3 (lower member of the Kızılırmak Formation). Left p3 (GK3-1), left m3 (GK3-2), GK3-3, right m2; GK3-4, left P2; GK3-5, right P4; GK3-6, left i1; GK3-7, left i2; GK3 A-8, fragmentary lower jaw preserving left $\mathrm{m} 1$; GK3-9, fragmentary right M3; GK3-11, right p3; GK3-12, phalanx media; GK3-13, phalanx proximalis; GK3-14, phalanx media; GK3-15, phalanx media; GK3-16, phalanx media; GK3 A-17, phalanx media; GK3-19, left calcaneum (damaged); GK3-20, distal pulley of right humerus; GK3-21, distal pulley of right humerus; GK3-22, distal pulley of left humerus; GK3-23, right calcaneum (damaged); GK3-24, left calcaneum (damaged); GK3-25, right astragalus (damaged); GK3-46, phalanx proximalis; GK3-27, posterior half of right p4; GK3-28, fragmentary right upper molar; GK3-29, labial half of left lower molar; GK3-30, fragmentary left lower molar preserving $M$ Structure; GK3-31, complete left M2; GK3-32, right edentelous lower jaw; GK3-33, right fragmentary lower jaw preserving m1?; GK3-34, left m2; GK336, right p4; GK3-37, right astragalus; GK3-38, right astragalus (damaged); GK3-39, right astragalus (damaged); GK3-54, proximal part of fused metatarsal III and IV.

Bağdatlı (upper member of the Kızılırmak Formation). BA-10, distal extremity of femur (damaged).

Tepe 641 (upper member of the Kızılırmak Formation). TP641-1, lower jaw preserving the talonid of $\mathrm{m} 1$ and the trigonid of $\mathrm{m} 2$; TP641-2, left $\mathrm{m} 3$; TP641-3, left m2; TP641-4, left m1; TP641-5, left $\mathrm{m} 1$; TP641-6, lower jaw preserving right $\mathrm{m} 2$; TP641-7, lower jaw preserving right m2; TP641-8, lower jaw preserving heavily worn m1-2; TP641 A11, lingual part of left M2?; TP641-12, right M2; TP641-13, left M1; TP641-14, right M2?; TP64115, left cubonavicular; TP641-16, left cubonavicular; TP641-17, right calcaneum; TP641-18, left calcaneum; TP641-19, TP641-19, left calcaneum (damaged); TP641-20, left calcaneum (damaged); TP641-21, right astragalus (damaged); TP641-22, right astragalus (damaged); TP641-26, distal extremity of left tibia; TP641-27, lower jaw preserving left m3; TP641-28, fragmentary vertebrae; TP641-30, right distal tibia.

Type locality of the Kızılırmak Formation (upper member of the Kızılırmak Formation). KZ-4, distal extremity of a phalanx proximalis; $K Z 5$, distal extremity of phalanx proximalis; KZ-7, right $M 1$; $\mathrm{KZ}-8$, distal pulley of a metatarsus.

\section{Description and Comparisons}

Lower deciduous dentition (based on the unique specimen GK2-11, Figure 3.6-7). The $d 3$ is anteroposteriorly elongated and transversely narrow as it is in non pecoran ruminants. The protoconid has an anterior crest extending to the anterior conid, which is slightly directed lingually as in Iberomeryx minor. The anterolingual conid is small, and a short crest extends anterolingually. The posterolingual cristid of the protoconid is short. The posterolabial conid is large and its posterior cristid extends posteriorly and turns lingually to form the posterolabial edge of the tooth as in Iberomeryx minor (Geraads et al., 1987). There is a thin cingulid on the anterolabial part of the tooth. The $\mathrm{d} 4 \mathrm{is}$ badly damaged and only the posterior lobe is preserved. The hypoconid and entoconid are of the same size. The entostylid is salient and separated 


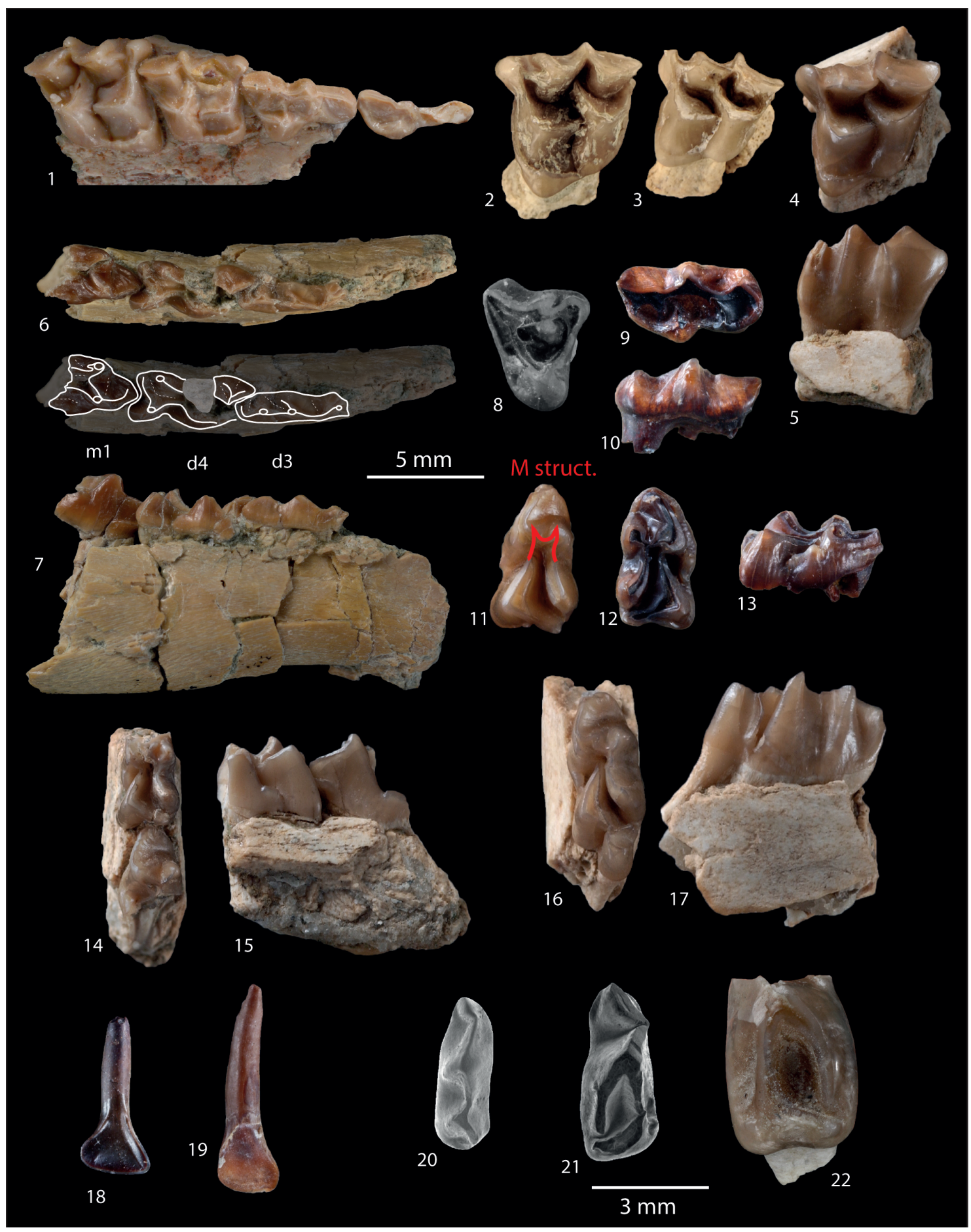

FIGURE 3. Dental remains of Iberomeryx parvus and Iberomeryx sp. from the Kızılırmak Formation (early late Oligocene, Central Anatolia). Iberomeryx parvus : 1, Right maxilla with D2-M1 in occlusal view, GK2-4; 2, Left M2 in occlusal view, GK3-31; 3, Left M1 in occlusal view, KZ-7; 4-5, Left M2 in occlusal (4) and labial (5) views, TP641-12; 6-7, Right lower jaw with d3-d4 and the trigonid of $\mathrm{m} 1$ in occlusal (6, with line drawing below) and lingual (7) views, GK2-11; 8, Right P4 in occlusal view, GK3-5; 9-10, Right P2 in occlusal (9) and labial (10) views, GK3-4; 11, Left m1 in occlusal view, TP641-4; 12-13, Right $\mathrm{m} 1$ in occlusal (12) and labial (13) views, GK3-3; 14-15, Left lower jaw with the talonid of $\mathrm{m} 1$ and the trigonid of $\mathrm{m} 2$ in occlusal (14) and labial (15) views, TP641-1; 16-17, Left lower jaw with m3 in occlusal (16) and lingual (17) views, TP641-2; 18, Left i1 in lingual view, GK3-7; 19, Left i2 or i3 in lingual view GK3-6; 20, Right p3 in occlusal view, GK3-11; 21, Right p4 in occlusal view, GK3-36. Iberomeryx sp.: 22, Talonid of a left p4 in occlusal view, GK3-35. The scale bar $3 \mathrm{~mm}$ goes exclusively with the views 20 to 22 . 
from the posteriorly rounded entoconid by a distinct groove. The external postprotocristid is preserved and observed linked to the prehypocristid as it is in all tragulids known so far. The posterior rim of the d4 is damaged and deforms the posthypocristid. There is no ectostylid but a cingular shelf.

Upper deciduous dentition (based on the unique specimen GK2-4, Figure 3.1). The D2 is fragmented and missing the antero-lingual part. The tooth is anteroposteriorly elongated and transversely narrow, and it has a strong posterolingual cingulum, and a smaller anterolabial cingulum. Unlike the D2 of Dorcatherium, there is a distinct lingual cone emerging from the lingual cingulum. The paracone (positioned at about midway of the tooth length) has a weak labial rib and strong anterolabial and posterolabial crests. There is a posterolingual cingulum between the paracone and the posterior corner of the tooth. The D3 has a similar configuration of cones and crests, but exhibits a triangular shape in occlusal view due to the larger lingual cone (metaconule) that is positioned at a more anterior level than the paracone. The labial rib of the paracone is more marked than on the D2, and the metacone bears a weak labial rib. The lingual cone (metaconule) has four crests. Its posterior crest fuses with the posterior cingulum. There is a well-marked internal transversal crest, and the anterior crest is split into a short internal crest and a posterior one which fuses with the anterolingual cingulum. The styles are weak, and there is no labial cingulum. The D4 has the configuration of the upper molars of adults, but it has a trapezoidal outline in occlusal view, and slightly more pronounced styles than on the molars. The protocone is sickle-shaped in occlusal view with an anteroposteriorly oriented postprotocrista. The metaconule is crescent-shaped with a premetaconulecrista ending between the paracone and metacone, and a slightly curved postmetaconulecrista joining the postero-labial corner of the tooth. The metastyle is absent. The paracone and metacone are aligned, and only the paracone displays a weak labial rib. The mesostyle forms a small column. There is an anterolingual cingulum surrounding the protocone.

Adult dentition. The lower incisors are tentatively referred to Iberomeryx parvus on the basis of their size, and the spatula-like morphology (especially i1) that is reminiscent to that of Dorcatherium (Kaup, 1839; Aiglstorfer et al., 2014) and Tragulus. The roots of the teeth are cylindrical and more and less straight (Figure 3.18-19). The crown of the first lower incisor (Figure 3.18) is of spade-like shape, almost symmetrical, and lingually concave like in Dorcatherium (Kaup, 1839). Its lingual face bears an anterior crest, and the posterior border is bounded by a groove. The second or third incisors are more difficult to differentiate. They are pen-like, lingually concave, clearly assymetrical, and bear a small anterior crest on the lingual face, and a groove on the posterior rim (GK3-7) (Figure 3.19), like in the $\mathrm{i} 1$.

The anterior premolars are poorly represented in our material. The $\mathrm{p} 3$ is an elongated and narrow tooth. The mesolabial conid (protoconid) is the main cuspid and the anterolabial cristid is bent lingually to join a small anterior conid (Figure 3.20). The posterolabial cristid joins the posterolabial conid that extends posteriorly into a single crest that reaches the posterior border of the premolar. There is small posterior cingulid. This p3 corresponds well to the morphology and proportions of the p3 of Iberomeryx minor.

Overall, the p4 is in accordance with those of Iberomeryx parvus and $I$. minor with two crests running posteriorly from the apex of the mesolabial conid (protoconid) forming a deep, posterolingually open gulley (Figure 3.21). The p4 of $I$. parvus is gracile and its anterior conid is more pronounced than on $\mathrm{p} 3$. The anterolingual cristid extends anteriorly and turns anterolingually at the level of the anterior conid. There are anterolingual and anterolabial cingulids, and a postero-labial cingulid as in $I$. parvus. This strong crest corresponds to a wear facet, which is strongly worn in all p4s observed.

Lower molars are brachydont (although tooth crowns are taller than those of Iberomeryx minor), and the hypoconid and protoconid are crescentshaped (Figure 3.11-17). The trigonid is narrower than the talonid, and the protoconid is taller than the metaconid on unworn teeth. The preprotocristid extends anteriorly, and turns abruptly lingually along the anterior part of the molar, forming a low crest, reaching the lingual margin of the tooth. Because of the absence of a premetacristid, this large anterior fossid shows a broad lingual opening (Figure 3.12). The entoconid is cuspidate, transversely compressed, and slightly anterior to the hypoconid. The posterior face of the hypoconid is distinctly concave; the posthypocristid extends to the lingual margin of the tooth; the cristid obliqua (or prehypocristid) is connected to the external postprotocristid. This crest tends to vanish during early wear of the molars. The $M$ structure on the posterior side of the trigonid is well marked on the $\mathrm{m} 1$ and $\mathrm{m} 2$ (Figure 3.11). The lingual half of the $M$ structure is formed by the external and internal 
postmetacristid whereas the labial half of the $M$ structure is formed by the external and internal postprocristid. The internal postmetacristid and the internal postprotocristid are short and fused high to form a cristid that joins the prehypocristid (cristid obliqua). There is a distinct anterior basal cingulid extending anterolabially from the base of the preprotocristid, a strong and high posterior basal cingulid, and a low and poorly expressed ectostylid.

The upper premolars are rare and fragmentary. The only available P2 is an elongate tooth with a thin lingual cingulum from which emerges a tiny cusp, which may be interpreted as an incipient protocone (Figure 3.9-10). The labial wall of P2 forms a distinct rib at mid-length of the tooth. The only P4 is triangular in occlusal outline (Figure 3.8), its posterior style is prominent, and its lingual protocone is fairly crescentic on this unworn tooth. The posterolingual crista is taller and more salient than the anterolingual crista, and it connects labially the posterior style.

The upper molars are trapezoidal in occlusal outline because of the enlargement of the labial (stylar) area (Figure 3.2-4). They show a very strong lingual cingulum extending around the base of the protocone, forming a shelf, but there is no trace of protoconule as in Nalameryx. The styles are strong, anteroposteriorly compressed, and salient labially. The paracone has a strong, asymmetrical, and salient labial rib; the labial side of the metacone is flat and not excavated as in $N$. savagei; the enamel is smooth.

Postcrania. Fragmentary postcranial material is tentatively attributed to $I$. parvus, in regard to its size, and because this species is largely dominant in our sample. The postcranial morphology of Oligocene tragulids is almost unknown (with exception of the astragalus, and distal metatarsal, Sudre, 1984), and we based the comparisons with the postcranial data known for the Miocene tragulid Dorcatherium (Kaup, 1839), Paleogene traguloids (Webb and Taylor, 1980; Vislobokova, 2001), and extant tragulids.

The forelimb remains consist of a distal part of a right humerus, and a distal extremity of a metacarpal. The distal epiphysis of the humerus is gracile and resembles overall to that of extent Tragulus. The condylus humeri is trapezoidal, and the lateral diameter of the trochlea is smaller than the medial one (Figure 4.9-11). The sagittal crest is wellmarked, and the groove between the medial and lateral part of the trochlea is more concave than in pecoran humeri. The medial epicondyle is snoblike and rather extended caudally (Figure 4.11) compared to extant tragulids. The deep olecranon fossa perforates the shaft, forming a supratrochlear foramen as in Hypertragulus and Tragulus. The coronoid fossa is well-marked and oval-shaped. The lateral capitulum is more or less circular in lateral view, and it has a sharp lateral border like in extant tragulids.

The tarsal bones are fairly well represented with cubonaviculars, astragali, and calcanei. Three classes of size can be distinguished among the cubonaviculars and astragali; this is less obvious in calcanei. We consider that the smallest tarsal elements (Figure 4.1-3) might belong to a small species of tragulid, even if there is so far no dental material that would correspond to such a small size.

The cubonaviculars show the same morphology with the exception that the facet for the calcaneum appears to be reduced when the size increases (Figure 4.1, 4.4, 4.17). Unlike most tragulids, none of them display a fusion with the ectocuneiform.

As in all traguloids, the proximal and distal trochleae of the astragalus are not aligned, and the distal trochlea is slightly rotated medially and transversely narrow. The astragalus of Iberomeryx parvus is anteroposteriorly elongated and overall more gracile than it is in Pecoran ruminants. The sustentacular facet is medially bordered by a distinct but weak ridge reducing the transverse development of the facet in plantar view (Figure 4.5-6). The sustentacular facet is concave due to the presence of a longitudinal groove extending anteroposteriorly. The distal trochlea does not show any ridge separating the articular surfaces of the cuboid and the navicular. The astragalo-calcaneal facet is welldeveloped, and there is a deep fossa for the fibular condyle of the calcaneum (Figure 4.8). The distal astragalar facet is generally well- developed as it is in the primitive Pecora. The distal part of the internal malleolus facet is wide in all the known specimens.

The number of calcanei is more reduced, and the size range may reflect the intraspecific variation. The lateral side of the calcaneum has a long, deep groove. The sustentacular process is rather prominent, and its articular surface for the astragalus is wide and divided into two parts. The fibular condyle has a narrow convex facet for the fibula (Figure 4.7-8). When preserved, the astragalo-calcaneal facet is reduced in size compared to pecoran ruminants.

The proximal part of a central right metatarsal shows fused metatarsal III and IV (Figure 4.12). 


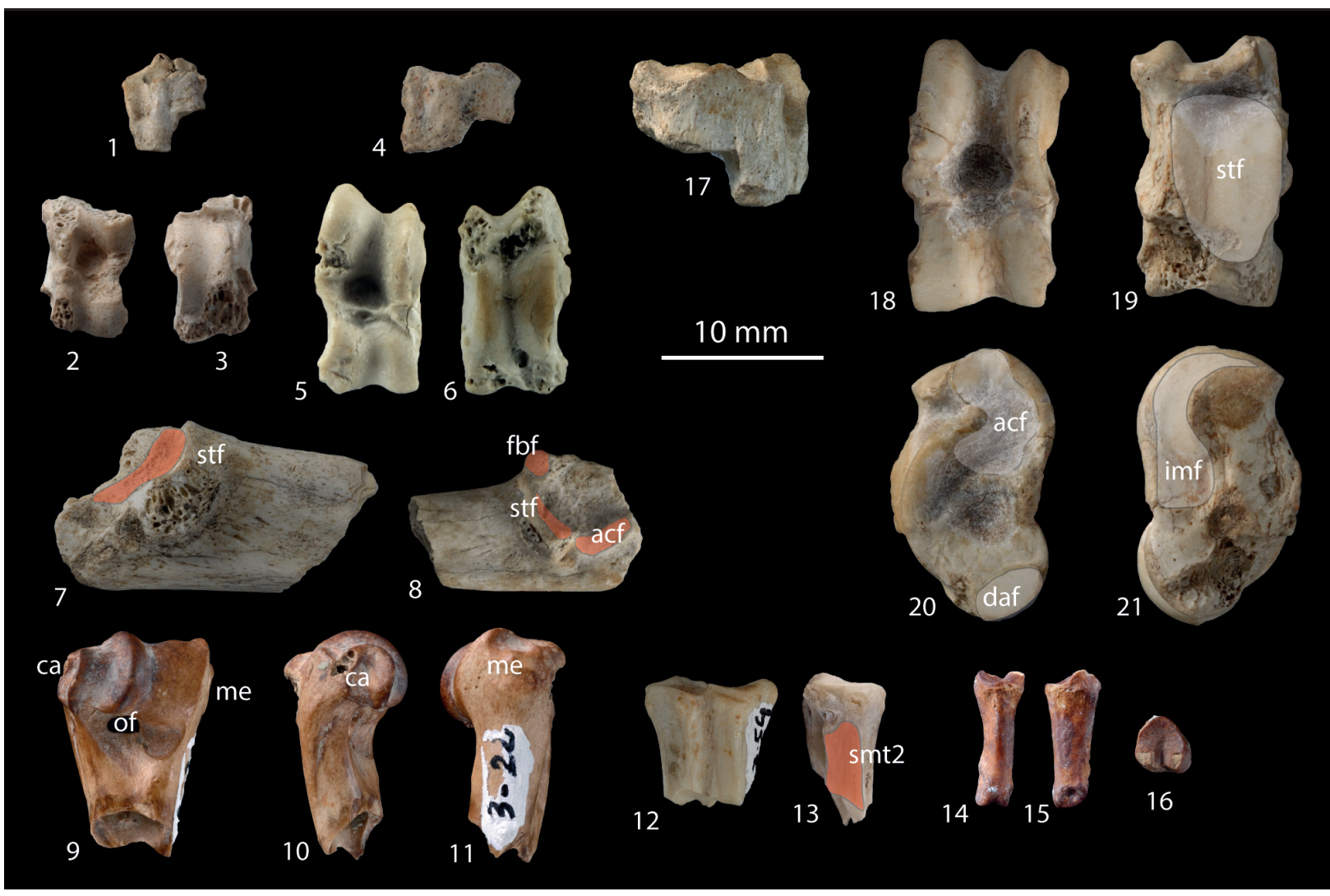

FIGURE 4. Postcranial remains of Iberomeryx parvus and Iberomeryx sp. from the Kızılırmak Formation (early late Oligocene, Central Anatolia). Iberomeryx parvus: 1, Right cubonavicular in anterior view, TP641-16; 2-3, Right astragalus in anterior (2) and posterior (3) views, GK3-39; 4, Right cubonavicular in anterior view, GK2-5; 5-6, Right astragalus in anterior (5) and posterior (6) views, GK3-37; 7, Left calcaneum in medial view, GK3-24. 8, Right calcaneum in medial view, KZ-11; 9-11, Left distal humerus in anterior-cranial (9), lateral (10), and medial (11) views, GK3-22; 1213, Proximal part of coalescent metatarsals III and IV in anterior (12), and medial (13) views, GK3-54; 14-16, phalanx proximalis in anterior (14), lateral (15), and proximal views, GK3-13; Iberomeryx sp. 17, Left cubonavicular in anterior view, KZ-2; 18-21, Right astragalus in anterior (18), posterior (19), lateral (20), medial (21) views, TP641-24. Anatomical abbreviations: acf, astragalo-calcaneal facet; ca, capitulum; daf, distal astragalar facet; fbf, fibular facet; imf, internal malleous facet; me, medial epicondyle; of, olecranon fossa; smt2, contact surface of the Mt2; stf, sustentacular facet.

The bone is longitudinally broken, but there is a flattened surface (Figure 4.12-13) on the medial part suggesting the presence of a metatarsal II as in I. minor (Blondel, 1997). A proximal phalange is also tentatively referred to I. parvus (Figure 4.14$16)$. The proximal articulation is wide and the dorsal border is robust and high. The distal articulating surface is concave and of rather rounded outline. The plantar edge of the articular surface contains a strong indentation (Figure 4.16), which corresponds to the incomplete keel of the metacarpal head like in tragulids. This indentation extends on between third and half of the length of the articulating surface. The distal pulley is transversely compressed. It is morphologically most similar to those of Archaeomeryx although more gracile.
Discussion. In specimen numbers, Iberomeryx parvus is the most common ruminant taxon in the Kızılırmak Formation. The material recorded is the most extensive available for that species, making it especially valuable for our knowledge of this taxon. The dental and postcranial material described above is clearly referable to tragulids because of the morphology of $\mathrm{d} 3$ (anteroposterior elongation and short lingual cristids), d4 (external postprotocristid connected to the prehypocristid), the structure of the p4 with a deep groove posterolingually opened at the rear of the protoconid, and the lower molars showing the characteristic $M$ structure. The morphology of the distal radius is also typical of tragulids. The thorough comparisons with the holotype of $I$. parvus (lower jaw preserving p4-m2) 
shows a general similar dental pattern, but the orientation of the prehypocristid is very labial, and it tends to connect the preentocristid, obliterating partially the $\mathrm{M}$ structure. The narrowness of the trigonid of molars, the elongated anterolingual preprotocristid, and the lack of premetacristid are typical features of Iberomeryx. It is worth noting that the upper deciduous dentition of the genus is here described for the first time. The D2 is not known for most Oligocene ruminants, and comparisons are necessarily limited. However, the D2 is more reminiscent to that of the extant genus Tragulus than to any Pecora which display a molarized D2 with a wider lingual extension. The D3 is most similar to that of Lophiomeryx chalaniati although the latter does not have a labially ribbed paracone nor the transverse crest linking the paracone and the protocone. The post-cranial material, especially the astragalus, displays the typical traguloid (Lophiomerycidae and Tragulidae) morphology, and it is in a size range that fit with the expected size range of the tooth sample (Tables 1 and 2), and it is thus naturally referred to as Iberomeryx.

This genus (also known as Cryptomeryx in the literature) was referred to tragulids by Sudre (1984), and to lophiomerycids by Janis (1987). These two families display, during the Paleogene, a characteristic morphology of the lower molars with a trigonid lingually opened (i.e., the anterior face of the metaconid is devoid of cristid). Recently, Mennecart et al. (2011) provided a systematic review of the Western European species $I$. minor and convincingly proposed the re-affiliation of Iberomeryx to the Tragulidae based mostly on the presence of the typical M structure on the lower molars; a character that is now considered as an important apomorphic feature of the family although not all tragulids display such a dental structure (e.g., Rössner, 2007). The Paleogene fossil record of tragulids is only documented by four genera, all are rather poorly known. The earliest record of tragulids is from the late Eocene lignite of Krabi (Southern Thailand) with Archaeotragulus krabiensis which bears the typical $\mathrm{M}$ structures on its lower molars (Métais et al., 2001), and the more ambiguous the earliest representative of the family, is known from the late Eocene of Thailand (Métais et al., 2001). Krabitherium waileki is another enigmatic bunoselenodont form from Krabi that has been tentatively considered as a tragulid (Métais et al., 2007). According to these authors, Krabitherium waileki might be an early precursor of the bunoselenodont linage represented by the Miocene genus Dorcabune and the extant tragulid Hyemoschus (Métais et al., 2007). Although the distinctive dental features are tenuous, the lower molars of Archaeotragulus differ from those of Iberomeryx in being more brachydont, the cristid obliqua more lingually orientated, the absence of ectostylid, and the pinched and transversely compressed hypoconulid (Métais et al., 2001). During the Oligocene, the family is known in Western Europe, Georgia, and in the Indian Subcontinent if Nalameryx is considered as a tragulid (Métais et al., 2009, 2015). The genus Iberomeryx is based on the species I. parvus Gabunia 1964, which is so far restricted to the late Oligocene of Benara (Georgia). In Western Europe, the genus is documented by the sole species I. minor (Filhol, 1882), which is known in several early Oligocene localities (MP23) (Mennecart et al., 2011). Among tragulids, the material described above is closest dentally to Iberomeryx and Nalameryx. The lack of protoconule on the upper molars, the high-crowned teeth, and the lesser transverse development on our material are the main morphological features that prevent assignment to Nalameryx. The Turkish material differs from I. minor in having higher crowned molars, reduced labial ribs on the paracone and the metacone, and the morphology of the p3. Moreover, the lower molars of $I$. minor retain a small protoconulid (=paraconid) which is not present on the lower molars from the Kızılırmak Formation. However, our material is closely comparable to that of Iberomeryx parvus because of the morphology of its lower dentition, especially the p4. I. parvus also shows higher crowned cheek teeth, and square upper molars (Gabunia, 1964, personal observation), features that also characterise the material described above. Nevertheless, the fossil material from the Kızilırmak Formation differs from I. parvus from Benara in the reduction of the transverse development of its upper and lower molars, its higher crowned cheek teeth, and its slightly smaller size. It is worth noting that the upper molars from TP641 and Kızılırmak Type locality referred to $I$. parvus tend to show higher labial walls with a concomitant reduction of the labial ribs and the transverse width (Figure 3.4-5). Because of the incomplete material currently available, we prefer to refer the small tragulid from the Kızılırmak Formation to Iberomeryx parvus.

If the material here referred to $I$. parvus is homogeneous in terms of morphology, it has nevertheless a size range that suggests either a noticeable intraspecific size variation or the presence of several taxa (Tables 1 and 2). The largest 
TABLE 1. Measurements (in $\mathrm{mm}$ ) of the dental material of taxa discussed in the text from the different fossil localities of the Kızılırmak. The values in brackets designate the width of the trigonid of lower molars, the non-bracketed values the maximal width. The asterisk designates estimated values when material is slightly broken or heavily worn/digested.

\begin{tabular}{|c|c|c|c|c|}
\hline Specimen & Taxon & Tooth & Length & Width \\
\hline GK2-11 & Iberomeryx parvus & d3 & 4.8 & 1.3 \\
\hline GK2-11 & I. parvus & $\mathrm{d} 4$ & 4.7 & 2.3 \\
\hline GK3-6 & I. parvus & i2-3? & 3.2 & 2.5 \\
\hline GK3-7 & I. parvus & ¡1 & 2.4 & 2.9 \\
\hline GK3-11 & I. parvus & p3 & 3 & 1.2 \\
\hline GK3-36 & I. parvus & $\mathrm{p} 4$ & 4.4 & 1.9 \\
\hline GK3-8 & I. parvus & $\mathrm{m} 1$ & 5.3 & $2,8(2,2)$ \\
\hline $641-5$ & I. parvus & $\mathrm{m} 1$ & 5.5 & $2,9(2,6)$ \\
\hline $641-4$ & I. parvus & $\mathrm{m} 1$ & 5.4 & $3,2(2,5)$ \\
\hline GK3-3 & I. parvus & $\mathrm{m} 1$ & 5.6 & $3,1(2,6)$ \\
\hline GK3-42 & I. parvus & $\mathrm{m} 2$ & 6.1 & $3,4(2,9)$ \\
\hline $641-7$ & I. parvus & $\mathrm{m} 2$ & 6.3 & $3,4(2,6)$ \\
\hline $641-3$ & I. parvus & $\mathrm{m} 2$ & 6.8 & $3,7(3)$ \\
\hline GK3-34 & I. parvus & $\mathrm{m} 2$ & 7.2 & $4,5(3,4)$ \\
\hline GK3-33 & I. parvus & $\mathrm{m} 2$ & 6 & $3,5(2,9)$ \\
\hline $641-6$ & I. parvus & $\mathrm{m} 2$ & 7.1 & $4(3,1)$ \\
\hline $641-2$ & I. parvus & m3 & 7.8 & $3,4(2,9)$ \\
\hline GK3-2 & I. parvus & m3 & 7.9 & $3,1(2,7)$ \\
\hline GK2-4 & I. parvus & $\mathrm{D} 2$ & 5.1 & 2.1 \\
\hline GK2-4 & I. parvus & D3 & 5.2 & 2.8 \\
\hline GK2-4 & I. parvus & D4 & 4.5 & 4.4 \\
\hline GK2-4 & I. parvus & M1 & 5.3 & 5.2 \\
\hline GK3-4 & I. parvus & $\mathrm{P} 2$ & 6.3 & 3.7 \\
\hline GK3-5 & I. parvus & $\mathrm{P} 4$ & 3.8 & 4.4 \\
\hline $\mathrm{KZ}-7$ & I. parvus & M1 & 5.4 & 5.1 \\
\hline $641-13$ & I. parvus & M1 & 5.3 & 5.5 \\
\hline GK3-31 & I. parvus & M2 & 6.4 & 6.8 \\
\hline $641-12$ & I. parvus & M2 & 6.3 & 6.2 \\
\hline $641-14$ & I. parvus & M2? & 6.7 & 6.4 \\
\hline GK3-35 & I. sp. & $\mathrm{p} 4$ & $?$ & 3.2 \\
\hline $641-9$ & lophiomerycid indet. & p1? & 7.3 & 2.9 \\
\hline BA-3 & Dremotherium guthi & $\mathrm{m} 1$ & 10.1 & 7.9 \\
\hline BA-6 & D. guthi & M2? & 10.4 & $?$ \\
\hline $641-10$ & cf. Palaeohypsodontus sp. & M2? & $9,5^{*}$ & $?$ \\
\hline
\end{tabular}

astragalus and cubonavicular (Figure 4.4-6) are about twice the size of the smallest astragalus and cubonavicular in our sample (Figure 4.1-3). The estimates of body mass provided from the size of the astragalus (Martinez and Sudre, 1995) show that such a variation would not fit the size variation of Tragulus kanchil, the smallest extant tragulid (Table 3). Strikingly, this variation of size is not reflected in the dental material which is associated with the medium- and large-sized tarsal elements of our sample. Also, we cannot rule out that a small species of tragulid only represented by tarsal bones (Figure 3.1-3) is present in our sample. Since the material is limited, we prefer to consider provisionally that the population of Iberomeryx par- 
TABLE 2. Measurements (in $\mathrm{mm}$ ) of the postcranial material of taxa discussed in the text from the different fossil localities of the Kızılırmak Formation. The asterisk designates estimated values when material is slightly broken or heavily worn/digested. Abbreviations: prox for proximal.

\begin{tabular}{|c|c|c|c|c|}
\hline \multicolumn{5}{|c|}{ Humerus (distal) } \\
\hline & & width & lateral depth & medial depth \\
\hline GK3-21 & Iberomeryx parvus & 10.3 & 4.2 & 6.7 \\
\hline GK3-22 & I. parvus & 10 & 4.7 & 7.1 \\
\hline \multicolumn{5}{|c|}{ metacarpal III+IV (distal) } \\
\hline & & width & depth & \\
\hline GK3-54 & I. parvus & 8.9 & $?$ & \\
\hline \multicolumn{5}{|l|}{ astragali } \\
\hline & & length & prox width & distal width \\
\hline GK3-18 & I. sp. & 16.1 & $9,5^{*}$ & 8.7 \\
\hline $641-23$ & I. sp. & 15.9 & $9,0^{*}$ & $8,5^{*}$ \\
\hline $641-24$ & I. sp. & 16.6 & $9,6^{*}$ & $9^{*}$ \\
\hline $641-25$ & I. sp. & $15,5^{*}$ & $9,0^{*}$ & 8.8 \\
\hline GK3-25 & I. parvus & $12^{*}$ & $7,5^{\star}$ & $6,7^{*}$ \\
\hline GK3-37 & I. parvus & 13.1 & $7,0^{*}$ & 6.5 \\
\hline GK3-38 & I. parvus & $?$ & 5.7 & $?$ \\
\hline GK3-39 & I. parvus & $?$ & $6^{*}$ & $?$ \\
\hline $641-21$ & I. parvus & $?$ & $?$ & $5,5^{*}$ \\
\hline $641-22$ & I. parvus & 13.1 & 7 & 6.4 \\
\hline BA-2 & lophiomerycid indet. & $27^{*}$ & $?$ & $15^{*}$ \\
\hline KZ-9 & Pecora indet. & 30.7 & 19.6 & 19.1 \\
\hline
\end{tabular}

vus of the Kızılırmak Formation is highly variable in size.

$$
\text { Iberomeryx sp. }
$$

Figures 3.22, 4.17-21

Referred material. talonid of a left p4 (GK3-35), right astragali (GK3-18; TP641-23; TP641-24; TP641-25), fragmentary distal extremity of right tibia (KZ-1), left cubonavicular (KZ-2), distal extremity of a phalanx proximalis (KZ-3, BA-8, TP641-29), distal extremity of metartarsal (GK3$47)$, and right calcaneum (KZ-11).

\section{Description and Comparisons}

This large species of Iberomeryx is based on bones of the tarsus (Figure 4.17-21), a distal extremity of tibia, and a talonid of p4 (Figure 3.22), which do not fit within the size range of $I$. parvus, as deduced from the size variation of the extant tragulid Tragulus kanchil. Moreover, the estimates of body size (Table 3 ) made on the astragalus widely exceed the body size variation of the type of
I. parvus. The large $\mathrm{p} 4$, which is built on the same model as the p4 of $I$. parvus, is about twice the size of the latter (Figure 3.22). Likewise, there is no morphological difference between the postcranial bones of Iberomeryx sp. and those referred to $I$. parvus. Given the paucity of the present material and pending additional data, we prefer to leave this taxon as Iberomeryx sp.

\section{LOPHIOMERYCIDAE INDET.}

Figure 5.7-9

Referred material. right calcaneum (GK2-7 ; KZ$10)$, left calcaneum (BA-3), right cubonavicular (GK2-3), fragmentary astragalus (BA-2), distal extremity of metatarsal (KZ-8), and right $\mathrm{p} 1$ ? (TP641-9)

\section{Description and Comparisons}

In our sample, a cubonavicular and a calcaneum are about $50 \%$ larger than the largest astragali and cubonavicular referred to I. parvus (Figure 5.7 and 5.9). The cubonavicular has a large facet 
TABLE 3 (continued).

\begin{tabular}{|c|c|c|c|c|}
\hline \multicolumn{5}{|c|}{ cubonavicular } \\
\hline & & width & depth & max height \\
\hline GK2-5 & I. parvus & 9.2 & $8,0^{*}$ & $8,5^{*}$ \\
\hline $641-15$ & I. parvus & 10.8 & 9.8 & 10 \\
\hline $641-16$ & I. parvus & 7.6 & 6.2 & 8.9 \\
\hline GK2-3 & lophiomerycid indet. & 17.7 & $?$ & 16.7 \\
\hline \multicolumn{5}{|l|}{ calcanei } \\
\hline & & length & prox width & distal width \\
\hline GK2-7 & lophiomerycid indet. & $?$ & $15^{*}$ & $?$ \\
\hline BA-3 & lophiomerycid indet. & $?$ & $14^{*}$ & $11^{*}$ \\
\hline$K Z-10$ & lophiomerycid indet. & $?$ & $15^{*}$ & $?$ \\
\hline GK3-19 & I. parvus & $?$ & $7^{*}$ & $?$ \\
\hline GK3-23 & I. parvus & $21^{*}$ & $7,5^{*}$ & 5.5 \\
\hline GK3-24 & I. parvus & $18^{*}$ & $?$ & $4^{*}$ \\
\hline $641-17$ & I. parvus & $17,5^{*}$ & $?$ & 4.4 \\
\hline $641-19$ & I. parvus & $18^{*}$ & $7^{*}$ & 4.5 \\
\hline$K Z-11$ & I. sp. & $?$ & $11^{*}$ & $?$ \\
\hline \multicolumn{5}{|c|}{ phalanx prox } \\
\hline & & length & prox width & distal width \\
\hline GK3-13 & I. parvus & 8.7 & 3.2 & 2.4 \\
\hline GK3-46 & I. parvus & $?$ & $?$ & 3.3 \\
\hline $\mathrm{KZ}-4$ & I. parvus & $?$ & $?$ & 3.1 \\
\hline$K Z-5$ & I. parvus & $?$ & $?$ & 2.8 \\
\hline $\mathrm{KZ}-6$ & I. parvus & 13.4 & 4.4 & 2.7 \\
\hline $641-29$ & I. sp. & 13.2 & 5.2 & 4 \\
\hline $\mathrm{KZ}-3$ & I. sp. & $?$ & $?$ & 5 \\
\hline BA-8 & I. sp. & $?$ & $?$ & 6.5 \\
\hline
\end{tabular}

for the calcaneum as in Lophiomeryc chalaniati. The sustentaculum tali, although broken, is massive, and the anterior border of the calcaneal tali is slightly inclined as in $L$. chalaniati. A leaf-like tooth is identified as a p1 (Figure 5.8) and it is most similar to the $\mathrm{p} 1$ of $L$. chalaniati. Although limited, this material leads us to suspect the presence in the fauna of a large Lophiomeryx-like ruminant that would be slightly smaller in size than $L$ chalaniati, a species known from the late Oligocene of Western Europe.

\section{PECORA INDET. \\ Figure 5.10-11}

Referred material. right astragalus (KZ-9), fragmentary distal extremity of left tibia (BA-5)

\section{Description and Comparisons}

A unique and undamaged astragalus in our sample is much larger than the largest astragali referred to I. parvus. It is also larger than the lophiomerycid reported above (Table 3 ). Moreover, unlike all the astragali of our present sample, it is the only specimen having the proximal and distal trochlea aligned, thus suggesting Pecoran affinities of this taxon (Figure 5.10-11).

Family indet. 1

Genus DREMOTHERIUM Geoffroy Saint-Hilaire, 1833

Type species. D. feignouxi Geoffroy Saint-Hilaire, 1833 
TABLE 3. Comparison of body mass estimations of taxa documented by an astragalus using the astragalus size (Wastragalus) from the method developed in Martinez and Sudre (1995), and comparisons with the mass range of the extant Tragulus kanchil (from Meijaard and Groves, 2004). The estimated body mass of I. parvus from Benara was obtained by using the $\mathrm{m} 1$ area (Wm1) of the type specimen (Gabunia, 1964, p. 182) and the method of Legendre (1989).

\begin{tabular}{llc}
\hline & \multicolumn{1}{c}{ Taxon } & $\begin{array}{c}\text { Estimated body mass } \\
\text { (Kg) }\end{array}$ \\
\hline TP641-21 & Iberomeryx parvus & 1.4 \\
GK3-25 & I. parvus & 2 \\
TP641-22 & I. parvus & 2.1 \\
GK3-37 & I. parvus & 2.2 \\
TP641-24 & I. sp. & 6.1 \\
GK3-18 & I. sp. & 5.9 \\
type (p4-m2) & I. parvus & 2.6 \\
& Tragulus kanchil & 1500 to 2500 \\
KZ-9 & large Pecora indet. & 38 \\
\hline
\end{tabular}

Dremotherium guthi Jehenne, 1987

Figure 5.1-4

Referred species. D. guthi Jehenne, 1987, D. cetinensis Ginsburg, Morales and Soria, 1994

Referred material. Bağdatlı, left m1 (BA-3); labial part of a left upper molar (BA-6).

\section{Description and Comparisons}

The lower molar (presumably an $\mathrm{m} 1$ because of its size, the lack of a contact surface on the base of the anterior side of the molar, and the wellmarked external postprotocristid) is relatively fresh, and its enamel is wrinkled (Figure 5.2). The lingual ribs of the metaconid and entoconid are barely visible (they are well-developed in $D$. feignouxi), and the wall of the molar is almost flat. The posthypocristid reaches the posterior base of the entoconid where it forms a small bulge. The anteroposterior axis of the metaconid is shifted obliquely with respect to that of the entoconid; the metastylid is small. The external postprotocristid is well-marked and does not connect to the prehypocristid as in tragulids. The anterior cingulid is better developed than the posterior cingulid. The fragmentary upper molar (BA-6) is badly damaged (Figure 5.4). Unlike the upper molar tentatively referred to Palaeohypsodontus (Figure 5.5-6), the central fossette between the paracone and metacone is large (this feature is accentuated by the heavy wear of the molar). The styles are moderately developed and the paracone has a strong labial rib. Such a morphology is compatible with that of the upper molar figured in Jehenne (1987).

This species is known from latest Oligocene localities of Europe where it is restricted to the mammal levels MP 29 to MP 30 (Jehenne, 1987; Scherler et al., 2013; Mennecart, 2015) while the type species $D$. feignouxi is restricted to the earliest Miocene (Aquitanian, MN1-2; Jehenne, 1987; Scherler et al., 2013). D. guthi is smaller than $D$. feignouxi, and its metastylid on the lower molars is supposedly less developed (Jehenne, 1987). The external postprotocristid is not signaled as a diagnostic feature of this species, but we have observed such a crest on $D$. feignouxi and it is present but weaker on D. guthi. The genus Dremotherium has been mentioned in Europe from different MP25 localities (Lavocat 1951; Ginsburg 1967; Hugueney 1997), but the identifications remain unsure, and such an early occurrence of the genus in Europe needs to be better documented.

In Central Asia, D. cf. guthi is reported from the upper Shand-Gol Formation at the Yagan Tologoi locality on the Dzabhan River (Vislobokova et al., 1996), and D. cf. guthi is also reported from the Biozone C (='Middle' Oligocene) of the Valley of Lakes, Central Mongolia (Vislobokova and Daxner-Höck, 2002). The age of Bağdatlı correlates with the mammal level MP27 (S. Sen pers. com.), and the occurrence of $D$. guthi in Central Anatolia thus predates the earliest occurrence of the species in Europe. According to Vislobokova and Daxner-Höck (2002, figure 9), their biozone $C$ is correlative to an early late Oligocene age (MP2526), making the Valley of Lakes occurrence the earliest occurrence of the genus.

Family indet. 2

Genus PALAEOHYPSODONTUS Trofimov, 1958 


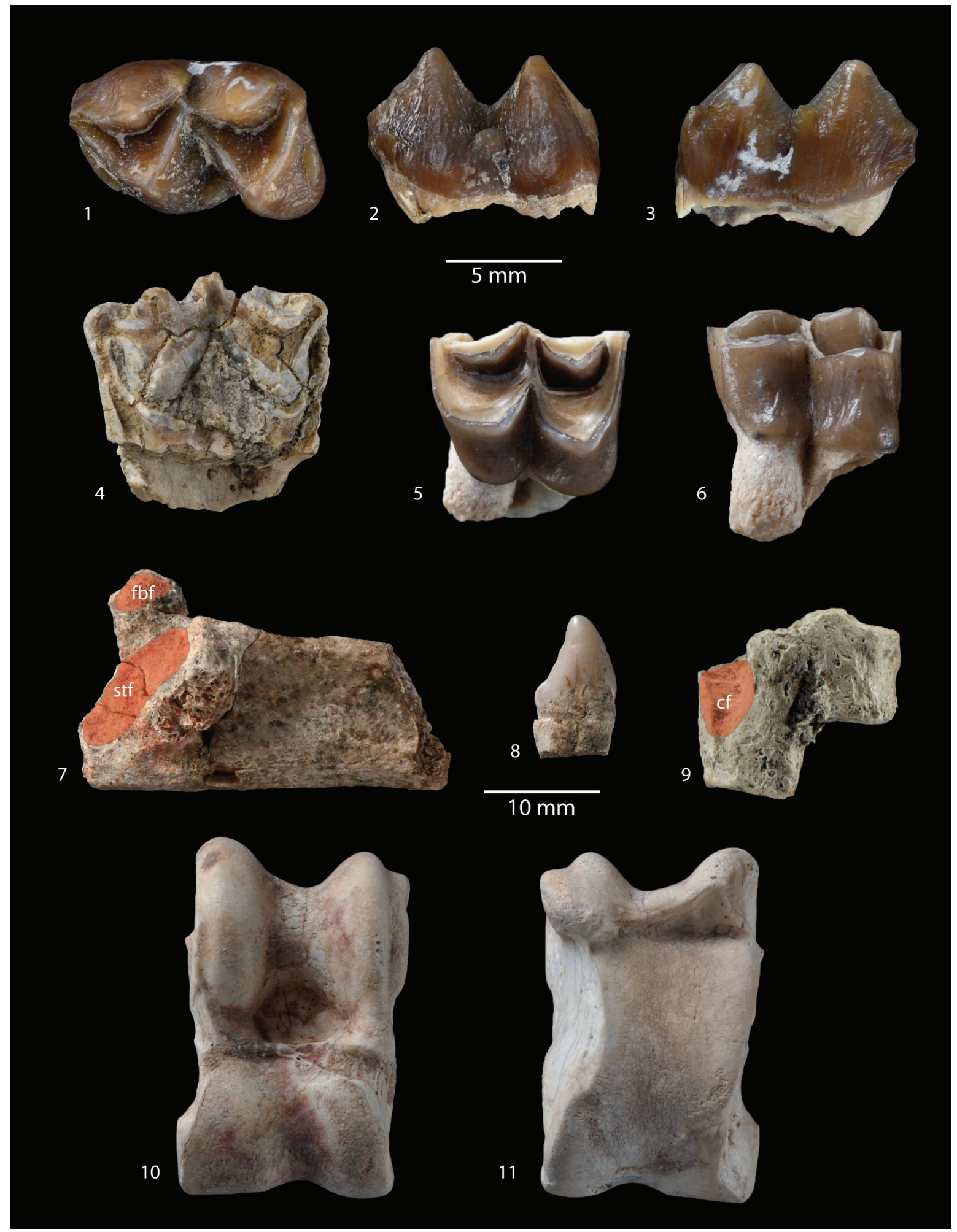

FIGURE 5. Dremotherium guthi: 1-3, Left $m 1$ in occlusal (1), labial (2), and lingual (3) views, BA-1; 4, M2? In occlusal view, BA-6; cf. Palaeohypsodontus sp.: 5-6, Right M2? in occlusal (5) and lingual (6) views, TP641-10; Lophiomerycidae indet.: 7, Right calcaneum in medial view, GK2-7; 8, Right p1 in labial view, TP641-9; 9, Right cubonavicular in anterior view, GK2-3. Large Pecora indet.: 10-11, Right astragalus in anterior (10) and posterior (11) views, KZ-9. Anatomical abbreviations: cf, calcaneal facet; fbf, fibular facet; stf, sustentacular facet. The scale bar 10 $\mathrm{mm}$ goes exclusively with the views 7 to 11 . 
TABLE 4. Occurrence of identified taxa in the different localities of the Kızılırmak Formation.

\begin{tabular}{lccccc}
\hline & GK2 & GK3 & Bagdatli & TP641 & Kz \\
\hline Iberomeryx parvus & $\mathrm{x}$ & $\mathrm{x}$ & $\mathrm{x}$ & $\mathrm{x}$ & $\mathrm{x}$ \\
Iberomeryx sp. (large) & & $\mathrm{x}$ & $\mathrm{x}$ & $\mathrm{x}$ & $\mathrm{x}$ \\
Lophiomerycidae indet. & $\mathrm{x}$ & & $\mathrm{x}$ & $\mathrm{x}$ & $\mathrm{x}$ \\
Dremotherium guthi & & $\mathrm{x}$ & & \\
cf Palaeohypsodontus sp. & & & $\mathrm{x}$ & \\
large Pecora indet. & & & $\mathrm{x}$ & & $\mathrm{x}$ \\
\hline
\end{tabular}

Type species. $P$. asiaticus Trofimov, 1958

$$
\begin{gathered}
\text { cf. Palaeohypsodontus sp. } \\
\text { Figure 5.5-6 }
\end{gathered}
$$

Referred species. P. zinensis Métais et al., 2003; $P$. sp. (cited in Vislobokova and Daxner-Höck, 2002).

Referred material. TP641-10, lingual part of upper molar.

\section{Description and Comparisons}

We have tentatively identified this genus on the basis of one fragmentary upper molar (the labial wall is lacking, Figure 5.5) from the locality Tepe 641. The protocone and metaconule are subequal in size, and highly crescent shaped and fully connected to the labial lobes. The crest resulting from the fusion of postprotocristid and the premetaconule-cristid plugs the central fossette of the molar. These crests are generally not fused in traguloids and Dremotherium even on highly worn molars. The tooth is moderately worn, and it is reasonable to suppose that the unworn teeth of the animal were high-crowned. The enamel is slightly wrinkled (Figure 5.6).

Although very fragmentary, this unique molar is highly reminiscent of that of the enigmatic genus Palaeohypsodontus Trofimov 1958, known from Oligocene deposits of Central Asia (Trofimov, 1958; Flerov, 1971; Dmitrieva, 2002), Mongolia (Vislobokova and Daxner-Höck, 2002), China (Huang, 1982, 1985), and Pakistan (Métais et al., 2003; Barry et al., 2005). It is worth noting that this taxon is mostly based on lower dentitions. However, Huang (1985) described upper molars that are tentatively referred to Palaeohypsodontus in regard to the "high-crowned" morphology of the material. Barry et al., (2005) also reported the lingual half of an upper molar without figuring it. We cannot determine the rank of the molar TP641-8 on the maxilla but it is an appropriate size for $P$. zinensis from the late Oligocene lower Chitarwata Formation in the Bugti Hills, Pakistan (Métais et al. 2003), and to a lesser degree for the material from
Ulan Tatal (Oligocene, China) referred to Palaeohypsodontus cf. asiaticus by Huang (1985). However, given the scarcity of the present material, we prefer to be cautious and to leave it as cf. Palaeohypsodontus sp. According to Barry et al. (2005), $P$. zinensis is also present in the lower Vihowa Formation in the Zinda Pir, which would represent the youngest occurrence of the species with an age of ca. 18.5 Ma (Lindsay et al., 2005; Antoine et al., 2013). The familial affinities and origin of this mesodont ruminant remains a tricky issue, because of its unexpected bovid-like dental morphology and the quasi absence of post-cranial information. Despite its antiquity, several authors have included this form within bovids although there is currently no evidence of cranial appendages in Palaeohypsodontus.

\section{SIGNIFICANCE OF THIS FAUNA}

\section{Biochronology}

The ruminant assemblage from the Kızılırmak Formation constitutes the first record of Paleogene ruminants in Turkey together with the record of Nalameryx in the late Oligocene deposits of Eastern Anatolia (Métais et al., 2015). This fauna includes taxa of typical late Oligocene range, thus documenting a particularly poorly known time interval for the ruminants' paleobiodiversity. The paucity of the ruminant material available at present does not provide relevant evidence to refine the time interval separating the different localities of the Kızılırmak Formation. Iberomeryx parvus has been recognized in the five localities, and the unidentified Lophiomerycidae in four localities (Table 4). Although the limited sample does not allow detecting any significant morphological differences between the different assemblages, the most reliable identifications (I. parvus and $D$. guthi) allow for biochronologic correlation with Western Eurasia. The ruminant fauna from the Kızılırmak Formation shows taxonomic affinities with the unique fauna of Asia Minor (Benara, Georgia), the late Oligocene 


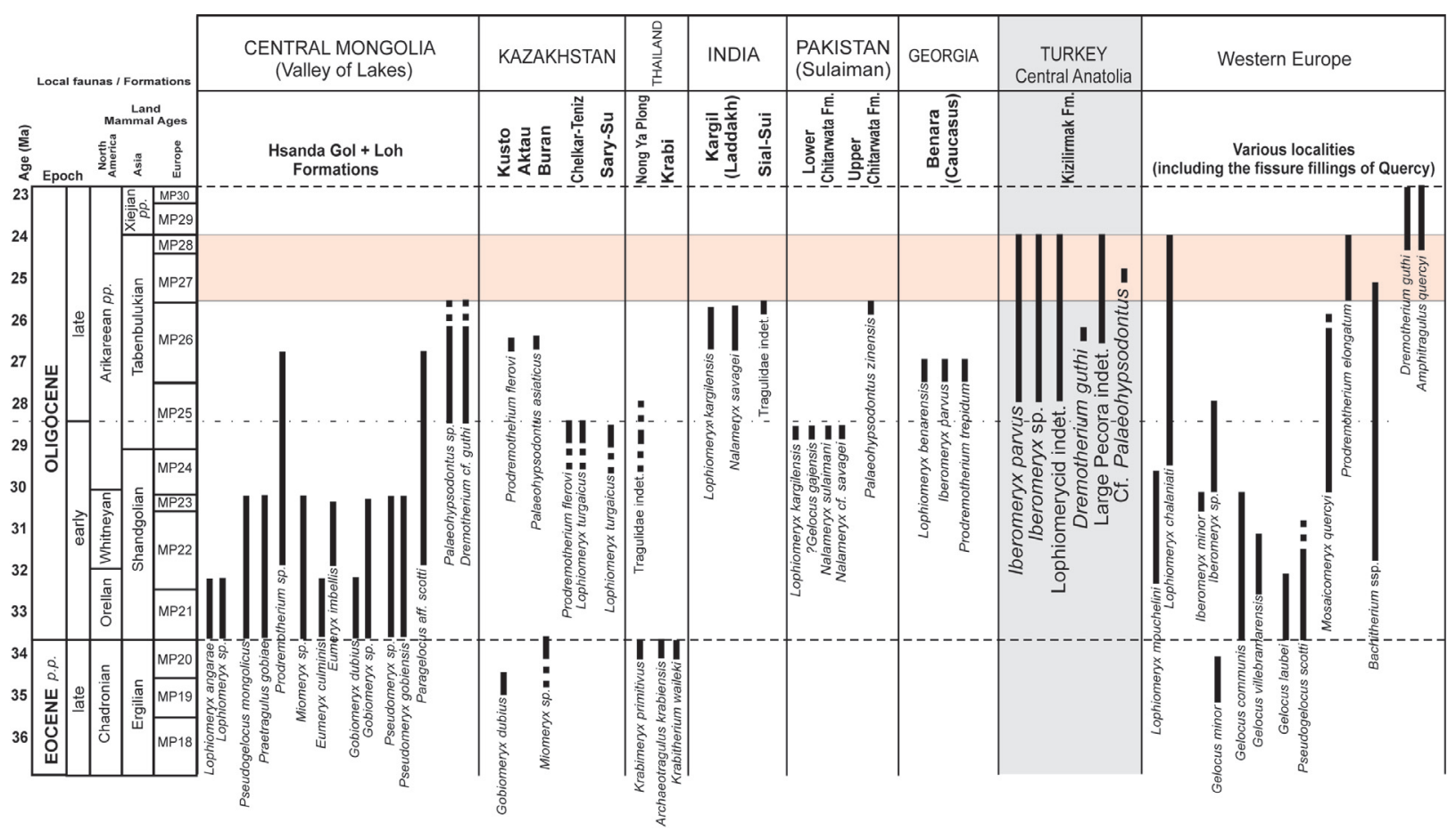

FIGURE 6. Stratigraphic ranges of late Eocene to Oligocene ruminant species in Eurasia (adapted from Métais and Vislobokova, 2007); the Land Mammal Ages are based on Tong et al. (1995), and Woodburne (2006). The colored area designates the duration of the late Oligocene Warming according to the chart of Zachos et al. (2001).

faunas of Western Europe, and also the Oligocene faunas of Central Asia. The genus Iberomeryx is represented in Western Europe by the sole species I. minor (Mennecart at al., 2011), and its stratigraphical range comprises essentially the Mammal Zone MP23 (early Oligocene) with a probable extension up to the 'middle' Oligocene MP25 (Sudre, 1995). However, Bağdatlı has yielded Dremotherium guthi, which is known in Western Europe from MP28 up to MP30. Dremotherium cf. guthi and Palaeohypsodontus sp. are also present in the biozone $\mathrm{C}$ of the Valley of Lakes in Central Mongolia (Vislobokova and Daxner-Höck, 2002). This biozone $\mathrm{C}$ corresponds to deposits lying immediately on a basalt dated to $28 \mathrm{Ma}$. Moreover, if our identification of Paleohypsodontus in the locality TP641 is correct, this would reinforce the late Oligocene age of the Kızılırmak Formation since this genus is mostly reported from late Oligocene deposits of Central and Southern Asia (Métais et al., 2003; Barry et al., 2005). The late Oligocene age suggested by the ruminant assemblage is consistent with the presence of the gigantic rhino Paraceratherium in the locality GK2, which is stratigraphically situated a few meters above the locality GK3 (Antoine et al., 2008). In the Bugti Hills of Pakistan, Paraceratherium is restricted to the
Oligocene Bugti Member, and does not persist up into the earliest Miocene (Antoine et al., 2013). The relative age of the Benara and Central Anatolian faunas is still difficult to establish. The Benara locality has also yielded the ruminants Lophiomeryx benaraensis and Prodremotherium trepidum, as well as rhinocerotoids, an entelodontid, anthracotheres, and carnivores (Gabunia, 1964). Several taxa among the rhinos and anthracotheres are common in the early Oligocene deposits of Asia and Europe (Lucas and Emry, 1999). Although much less documented, the Kızılırmak Formation has not yielded taxa with an early Oligocene age. Therefore, the fossil assemblages from the Kızılırmak Formation are probably slightly younger than that of Benara (Figure 6).

\section{Paleoecology - Paleoenvironments}

The localities GK2 and GK3 that lie near the base of the Kızılırmak Formation have only yielded traguloid ruminants whereas the localities of the upper part of the formation have yielded a more diversified assemblage. For example, the locality of Bağdatlı has yielded only a very limited number of specimens (12), but five taxa have been identified there. Likewise, the 'Kızılırmak type locality' have yielded a taxonomically relatively rich assemblage 
based on very few specimens. At this stage and given the taphonomic biases that can affect such fluvial deposits, it is difficult to know if the over-representation of traguloids in the base of the Kızılırmak Formation reflects different paleoenvironmental conditions than those of the upper Kızılırmak Formation. Likewise, many tiny remains (e.g., astragali) frequently show traces of abrasion or digestion indicating that the fossil material has been transported and therefore not well-suited for a thorough paleoecological study. Moreover, the lack of published magnetostratigraphic study prevents estimating the time registered in the thickness of the Kızılırmak Formation. However, the ruminant fauna provides indications of the global environment of Central Anatolia during the late Oligocene. The presence of probably several species of lophiomerycids which are generally considered as browsers (Janis, 1997), and tragulids suggests a rather tropical forested environment. The body size estimates for Iberomeryx parvus indicate a size close to or smaller than the extant Tragulus kanchil (Table 3) that lives in the tropical forest of Southeast Asia. Extant tragulids are selective browsers (fruit and dicot foliage) and have a fairly opportunistic diet with a significant amount of non-vegetal matter (Dubost, 1984). Tragulids are often thought of as ecological analogs for the ancestral ruminant and as such referred to as "living fossils" (Janis, 1984). Nevertheless, the Miocene fossil record clearly indicates that tragulids are distributed in larger areas (and climatic zones) of the Old World than nowadays, and their dietary reconstructions suggest a spectrum that ranges from fruit-dominated to pure browse diets and mixed diets (Clauss and Rössner, 2014). The dental material of $I$. parvus from TP641 generally displays higher crowned molars than those of the same species from GK23 , suggesting a shift towards a coarser and more abrasive diet or greater amounts of dust. This dental morphology may also be indicative of an increased openness of landscape, which is consistent with the presence of the giant rhino Paraceratherium that certainly did not live in a densely forested settings. Likewise, the presence of Dremotherium guthi, Palaeohypsodontus, other larger Pecoran ruminants, and the large rhino Paraceratherium suggests more open but non-grassy habitats, since grasslands including elements of fairly abrasive vegetation are unknown from the Oligocene in the Old World (e.g., Janis et al., 2002). According to Novello et al. (2010), D. guthi was a mixed feeder but close ecologically to extant graz- ers, that probably lived in mixed-environments. The faunal or floristic fossil evidence is still too poor for proposing a definitive picture of the paleoenvironmental conditions, but the preliminary results based on the entire faunal assemblage and sedimentary facies suggest a mosaic of both forested and more open landscapes close to fluvio-lascustrine settings. The palynological data suggest a forested environment with shallow lakes, and high percentages of Pinus and Quercus characterizing topographic highlands close to the depot center of the Kızılırmak Formation (Akgün et al., 2002). Overall, the floras indicate a subtropical climate in the region with possible seasonally dry areas away from the depositional sites (Akgün et al., 2002).

The late Oligocene is marked in Europe by drastic faunal changes (e.g., Blondel, 1997) that have recently been referred to as the "Microbunodon Event" because of the first appearance of this small anthracothere in Western Europe (Mennecart, 2015). The greatest turnover for ruminants occurred during the MP28 interval with the extinction of common early and early late Oligocene taxa (Bachitherium, Lophiomeryx and Prodremotherium), and the first appearance of stem pecoran ruminants such as Dremotherium guthi and Amphitragulus quercyi. This time interval (MP27-MP28) is correlated with important global climatic changes recorded isotopically in the marine realm (Zachos et al., 2001). Pekar at al. (2006) correlate this climatic warming with the reduction of the Antarctic ice volume during the late Oligocene. The abrupt drop of the 018 curve is thought to correspond to an increase of $\sim 4^{\circ} \mathrm{C}$ of ocean water during a very short interval (Zachos et al., 2001, De Man and Van Simaeys, 2004). In the Çankırı-Çorum Basin, this interval corresponds to the deposition of the upper part of the Kızılırmak Formation. It is worth noting that the evaporite-rich Güvendik Formation conformably underlies the Kızılırmak Formation, and at some points, it also inter-fingers with the latter formation, suggesting patterns of deposition with important lateral facies variations. The mostly evaporitic Güvendik Formation is thought to have been deposited under a dry climate in a large lake covering the present Bayat-Çiçekdağı-BalışeyhÇankırı region (Karadenizli, 2011). The age of the fossil localities of the Kızılırmak Formation are still to be refined but a tentative correlation to the GPTS based preliminary magnetostratigraphic results (in preparation) rather suggests that the formation would straddle the late Oligocene warming event (Figure 7). The fossil data currently available in Central Anatolia do not allow us to understand 


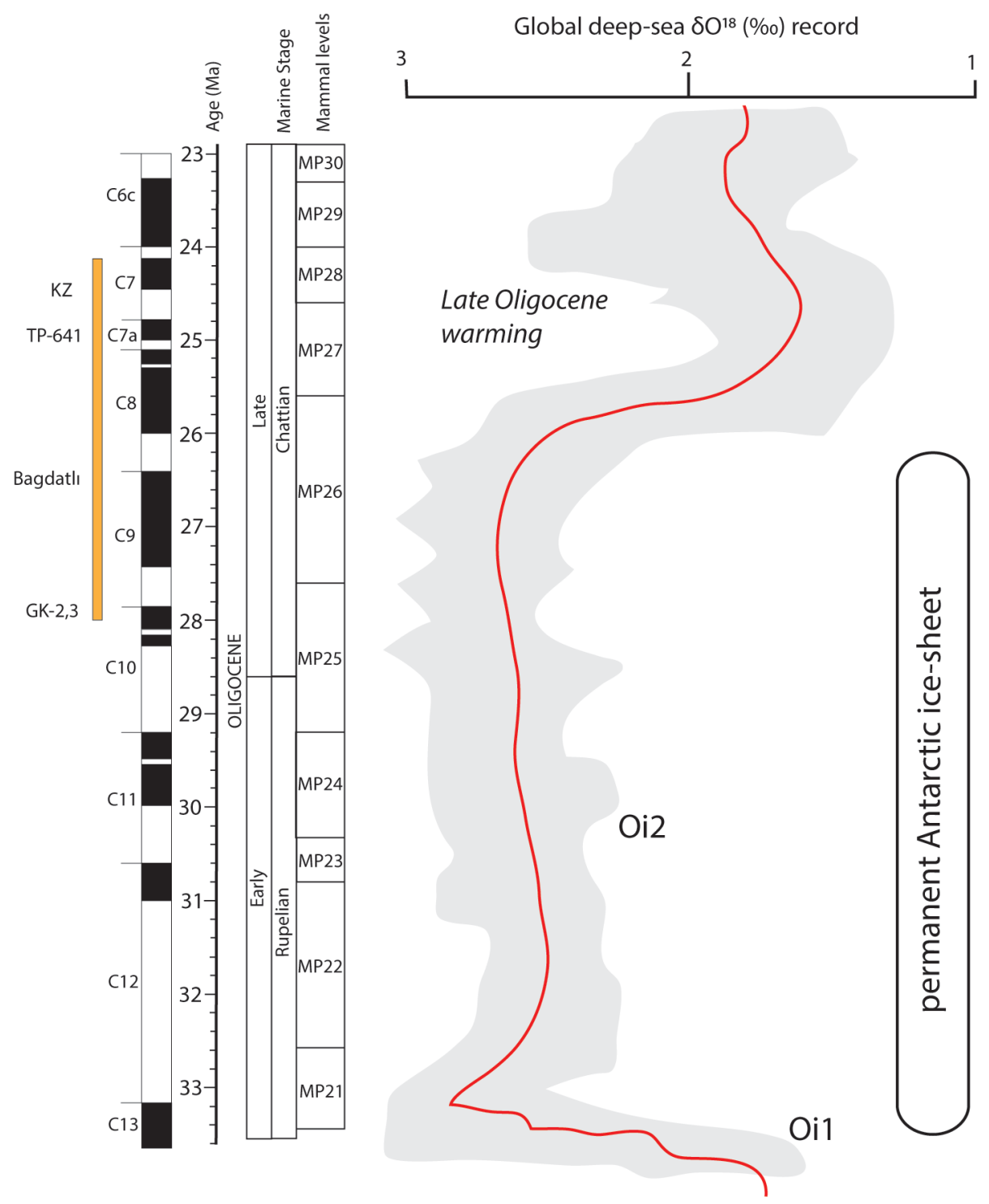

FIGURE 7. Oligocene chronostratigraphic chart indicating the preliminary ages of the different fossil localities based on the unpublished magnetostratigraphic study (Sevket Sen, personal commun., 2016), and the Paleoclimatic context during the Oligocene. Oi1 and Oi2 designate main cooling and glaciation events (Adapted from Berggren et al. 1995, and Zachos et al., 2001 for the paleoclimatic chart).

the potential effect of these climatic pulses on terrestrial ecosystems, including the mammal faunas. However, the climate may have been more humid than in Western Europe since tragulids are still present and fairly diversified in Central Anatolia at that time. However, additional fossil material from the Oligocene continental sequence exposed in the Çankırı-Çorum Basin would certainly contribute to improving these preliminary paleoenvironmental interpretations.

\section{Paleobiogeography}

The ruminant fauna from the Kızılırmak Formation displays taxonomic affinities with European and Asiatic sub-contemporaneous faunas. However, precise correlations are hampered by the scarcity of the material and the difficulties of identifying taxa. Ünay et al. (2003) claimed that the marked endemism of Central Anatolian rodent faunas during most of the Oligocene obstructed biochronologic correlations with Europe and Central 
Asia. According to Ünay et al. (2003) the 'middle' Oligocene rodent assemblages of Central Anatolia are impoverished, show a high degree of endemism, and differ very markedly from each other. The fragmentation of the Anatolian block into a number of islands is invoked to explain this paleobiogeographic pattern. However, the latest Oligocene assemblages show a re-connection to European and Asian regions. We do not see any trace of endemism in our assemblage covering the entire time of deposition of the Kızılırmak Formation. The localities GK2-3 do contain I. parvus, a form only known in Benara, and the localities situated in the upper Kızılırmak have yielded I. parvus and other taxa that show biogeographic affinities with both Europe and Central Asia (Figure 6). It is worth noting that the different assemblages of the Hsanda Gol and Loh formations in Mongolia cover much longer time intervals than the Kızılırmak Formation but have not yielded any tragulids. Moreover, lophiomerycids are only reported in biozone A which corresponds to the base of the Oligocene (the deposits characterizing this biozone are capped by a basalt dated to $31.5 \mathrm{Ma}$, [Vislobokova and Daxner-Höck, 2002]). Although collecting biases are always possible, it appears that very early during the Oligocene, the climate in Mongolia became drier or at least not favorable to the tragulids, and at lesser extent to lophiomerycids. This more seasonal and drier climate of Mongolia during the Oligocene may be related to the beginning of Tibetan Plateau uplift, and the related intensification of the Asian Moonson (Licht et al., 2014). During the late Oligocene, paleogeographic maps (Popov et al., 2004) indicate connection of Anatolia with the Asian mainland probably via complex foreand back arc basins in Eastern Anatolia and Lesser Caucasus (Métais et al., 2015). The geographic relationships of Anatolia with Western Europe may have been more episodic although land connection between the back see area and Western Europe is attested as early as late Eocene (Nikolov and Heissig, 1985). Additional fossil data from Anatolia and Eastern Europe (i.e., Balkans) are needed to better understand the paleobiogeograhy of ruminants along the northern Tethys during the Late Paleogene.

\section{CONCLUSIONS}

Numerous gaps subsist in our knowledge of circum-Tethyan mammalian evolution and biogeography before and around the Oligocene-Miocene transition. Central Anatolia is a key area for understanding biogeographic relationships and faunal exchanges within Eurasia as well as between southern Asia and Africa. The ruminant faunas recovered in the localities of the Kızılırmak Formation yield important clues about the early evolution and geographic distribution of traguloid and stem pecoran ruminants. Due to its age, the faunas from the Kızılırmak Formation documents a time interval for which very few data are available in Asia (Figure 6). The preliminary study of the ruminant fauna from the Kızılırmak Formation indicates clear faunal continuity with Europe and the Asian mainland during the late Oligocene, with some differences at the species level. The Kızılırmak Formation seems to cover a time interval that coincides with the outset of the late Oligocene Warming (Zachos et al., 2001) up to that the faunal remolding that affected Western Europe at MP28 (Mennecart, 2015). The occurrence of Dremotherium guthi in Central Anatolia predates its first appearance in Western Europe at MP28, and the occurrence of Pecoran forms as large as the indeterminate Pecora reported here is unknown in Eurasia during the late Oligocene. The assemblages from the base of the Kızilırmak Formation have exclusively yielded traguloid ruminants including Iberomeryx parvus and another larger species. The localities situated in the upper part of the Kızılırmak Formation (Bağdatlı, TP641, and Kızılırmak Type Locality) have yielded additional taxa, including several basal Pecoran. The dental material from TP641 referred to $I$. parvus displays higher crowned molars, suggesting a shift towards a coarser and more abrasive diet. The upper part of the Kızılırmak Formation probably was deposited during the late Oligocene warming that profoundly affected the terrestrial ecosystems. However, even if we could detect a change in dental morphology in I. parvus throughout the Kızılırmak Formation, our sample is not sufficient to go further in interpretation. Additional fossil material is also needed to demonstrate biogeographic relationships with roughly coeval faunas from Europe, Central Asia, and Southern Asia. The late Oligocene is marked by climatic pulses that generally favored dispersion across distinct biogeographic areas. From these preliminary results, it appears that the ruminant fauna from the Kızılırmak Formation is taxonomically most similar to Oligocene faunas from Europe and Central Asia, and to a lesser degree with Oligocene faunas of Pakistan (Barry et al., 2005; Métais et al., 2009). The Paleogene fossil record along the northern edge of the Tethys remains very scarce (Sen et al., 2011; Métais et al., 2015), and in that 
respect, the ruminant fauna from the Kızılırmak Formation provides a critical landmark.

\section{ACKNOWLEDGMENTS}

This work was carried out with the support of several agencies and institutions: the TÜBITAK, the CNRS, the MNHN, Paris, and the General Directorate of Mineral Research and Exploration (MTA, Ankara). We thank C. Karaca and C. Öztürk (MTA Museum, Ankara), and all the persons who contributed to the field work. We thank P. Loubry (UMR 7207-CR2P) for the photographs. GM thanks $\mathrm{J}$. van der Made for the good quality photos of the type of $I$. parvus. We thank the reviewers for their remarks that have improved the manuscript.

\section{REFERENCES}

Aiglstorfer, M., Rössner, G.E., and Böhme, M. 2014. Dorcatherium naui and pecoran ruminants from the late Middle Miocene Gratkorn locality (Austria). Palaeobiodiversity and Palaeoenvironments, 94:83-123.

Akgün, F., Akay, E., and Erdogan, B. 2002. Tertiary Terrestrial to Shallow Marine Deposition in Central Anatolia: A Palynological Approach. Turkish Journal of Earth Sciences, 11:127-160.

Antoine, P.-O., Karadenizli, L., Saraç, G., and Sen, S. 2008. A giant rhinocerotoid (Mammalia, Perissodactyla) from the late Oligocene of north-central Anatolia (Turkey). Zoological Journal of the Linnean Society, 152:581-592.

Antoine, P.-O., Métais, G., Orliac, M.J., Crochet, J.-Y., Flynn, LJ., Marivaux, L., Rajpar, A.R., Roohi, G., and Welcomme, J.-L. 2013. Mammalian Neogene biostratigraphy of the Sulaiman Province, Pakistan, p. 400-422. In Wang, X., Flynn, L.J., and Fortelius, M. (eds.), Fossil Mammals of Asia. Neogene Biostratigraphy and Chronology. California University Press, San Francisco

Bärmann, E.V. and Rössner, G.E. 2011. Dental nomenclature in Ruminantia: Towards a standard terminological framework. Mammalian Biology. Zeitschrift für Säugetierkunde, 76:762-768.

Barry, J.C., Cote, S., MacLatchy, L., Lindsay, E.H., Kityo, R., and Rajpar, A.R. 2005. Oligocene and early Miocene ruminants (Mammalia, Artiodactyla) from Pakistan and Uganda. Palaeontologia Electronica, 8:129.

Berggren, W.A., Kent, D.V., Swisher, C.C., and Aubry, M.-P. 1995. A revised Cenozoic geochronology and chronostratigraphy. Society for Sedimentary Geology, Special Publication, 54:129-212.

Blondel, C. 1997. Les ruminants de Pech Desse et de Pech du Fraysse (Quercy; MP 28); évolution des ruminants de l'Oligocène d'Europe. Géobios, 30:573591.
Böhme, M., Aigstorfer, M., Antoine, P.-O., Appel, E., Havlik, P., Métais, G., Phuc, L.T., Schneider, S., Setzer, F., Tappert, R., Tran, D.N., Uhl, D., and Prieto, J. 2013. Na Duong (Northern Vietnam): an exceptional window into Eocene ecosystems from South-East Asia. Zitteliana, A53:120-167.

Clauss, M. and Rössner, G.E. 2014. Old World Ruminant Morphophysiology, Life History, and Fossil Record: Exploring Key Innovations of a Diversification Sequence. Annales Zoologici Fennici, 51:80-94.

de Bruijn, H., Ünay, E., Saraç, G., and Yïlmaz, A. 2003. A rodent assemblage from the Eo/Oligocene boundary interval near Süngülü, Lesser Caucasus, Turkey. Coloquios de Paleontología Volumen Extraordinario, 1:47-76.

De Man, E. and Van Simaeys, S. 2004. late Oligocene Warming Event in the southern North Sea Basin: benthic foraminifera as paleotemperature proxies. Netherlands Journal of Geosciences/Geologie en Mijnbouw, 83:227-239.

Dmitrieva, E.L. 2002. On the early Evolution of bovids. Paleontological Journal, 71:86-88.

Dubost, G. 1984. Comparison of the diets of frugivorous forest ruminants of Gabon. Journal of Mammalogy, 65:298-316.

Filhol, H. 1882. Etude des mammifères fossiles de Ronzon (Haute-Loire). Annales des Sciences Géologiques de Paris, 12:1-33.

Flerov, K.K. 1971. Au sujet des plus anciens ruminants. Bulletin de la Société moscovite des Naturalistes, 6:34-40.

Gabunia, L.K. 1964. Benara fauna of Oligocene vertebrates. "Metsniereba" Press, Tbilissi.

Geoffroy Saint-Hilaire, E.F. 1833. Palaeontographie. Considérations sur des ossemens fossiles la plupart inconnus trouvés et observés dans les bassins de l'Auvergne. Revue encyclopédique (Paris), 54:76-95.

Geraads, D., Bouvrain, G., and Sudre, J. 1987. Relations phylétiques de Bachitherium Filhol, ruminant de l'Oligocène d'Europe occidentale. Palaeovertebrata, 17:43-73.

Ginsburg, L. 1967. L'âge relatif des gisements de mammifères de la Limagne d'Auvergne. Compte Rendu Sommaire des Séances de la Société Géologique de France, 7:325.

Ginsburg, L., Morales, J., and Soria, D. 1994. The ruminants (Artiodactyla, Mammalia) from the lower Miocene of Cetina de Aragon (Province of Zaragoza, Aragon, Spain). Proceedings of the Koninklijke Nederlandse Akademie van Wetenschappen (Series B), 97:141-181.

Görür, N., Oktay, F.Y., Seymen, I., and Şengör, A.M.C. 1984. Palaeotectonic evolution of the Tuzgölü basin complex, Central Turkey: sedimentary record of a Neo-Tethyan closure, p. 467-482. In Dixon, J.E. and Robertson, A.H.F. (eds.), The Geological evolution of the Eastern Mediterranean. Geological Society of London Special Publication, Blackwell Scientific, Oxford. 
Görür, N., Tüysüz, O., and Şengör, A.M.C. 1998. Tectonic evolution of the Central Anatolian Basins. International Geology Review, 40:831-850.

Huang, X. 1982. Preliminary observations on the Oligocene deposits and mammalian fauna from Alashan Zuoqi, Nei Mongol. Vertebrata PalAsiatica, 20:341349.

Huang, X. 1985. Fossil bovids from the middle Oligocene of Ulantatal, Nei Mongol. Vertebrata PalAsiatica, 23:153-160.

Hugueney, M. 1997. Biochronologie mammalienne dans le Paléogène et le Miocène Inférieur du Centre de la France: synthèse réactualisée. Mémoires et Travaux de l'institut de Montpellier de l'Ecole Pratique des Hautes Etudes, 21:417-430.

Janis, C.M. 1984. Tragulids as living fossils, p. 87-94. In Eldredge, N. and Stanley, S.M. (eds.), Living fossils. Casebooks in Earth Sciences, New-York-Berlin-Heidelberg-Tokyo.

Janis, C.M. 1987. Grades and clades in hornless ruminant evolution: the reality of Gelocidae and the systematic position of Lophiomeryx and Bachitherium. Journal of Vertebrate Paleontology, 7:200-216.

Janis, C.M. 1997. Ungulate teeth, diets, and climatic changes at the Eocene/Oligocene boundary. Zoology, 100:203-220.

Janis, C.M., Damuth, J., and Theodor, J.M. 2002. The origins and evolution of the North American grassland biome: the story from the hoofed mammals. Palaeogeography, Palaeoclimatology, Palaeoecology, 177:183-198.

Jehenne, Y. 1987. Intérêt biostratigraphique des ruminants primitifs du Paléogène et du Néogène inférieur d'Europe occidentale. Münchner Geowissenschaftliche Abhandlungen (A), 10:131-140.

Karadenizli, L. 2011. Oligocene to Pliocene palaeogeographic evolution of the Çankiri-Çorum Basin, central Anatolia, Turkey. Sedimentary Geology, 237:1-29.

Karadenizli, L., Saraç, G., Şen, Ş., Seyitoğlu, G., Antoine, P.-O., Kazancı, N., Varol, B., Alçiçek, M.C., Gül, A., Erten, H., Esat, K., Özcan, F., Savaşçı, D., Antoine, A., Filoreau, X., Hervet, S., Bouvrain, G., de Bonis, L., and Hakyemez, H.Y. 2004. Çankırı-Çorum havzasının batı ve güney kesiminin memeli fosillere dayalı Oligo-Miyosen biyostratigrafisi ve dolgulama evrimi. MTA report no 10706.

Kaup, J.-J., 1839. Description d'ossements fossiles de Mammifères inconnus jusqu'à présent, qui se trouvent au Muséum grand-ducal de Darmstadt. Cinquième cahier. J.P. Diehl, Darmstadt.

Koçyiğit, A. 1991. An example of an accretionary forearc basin from northern Central Anatolia and its implications for the history of subduction of Neotethys in Turkey. Geological Society of America Bulletin, 103:22-36.

Lavocat, R. 1951. Révision de la faune des mammifères Oligocènes d'Auvergne et du Velay. Science et Avenir Edition, Paris.
Legendre, S. 1989. Les communautés de mammifères du Paléogène (Eocène supérieur et Oligocène) d'Europe Occidentale: structures, milieux et évolution. Münchner Geowissenschaftliche Abhandlungen (A), 16:1-100.

Licht, A., van Cappelle, M., Abels, H.A., Ladant, J.B., Trabucho-Alexandre, J., France-Lanord, C., Donnadieu, Y., Vandenberghe, J., Rigaudier, T., Lecuyer, C., Terry Jr, D., Adriaens, R., Boura, A., Guo, Z., Soe, A.N., Quade, J., Dupont-Nivet, G., and Jaeger, J.J. 2014. Asian monsoons in a late Eocene greenhouse world. Nature, 513:501-506.

Lindsay, E.H., Flynn, L.J., Cheema, I.U., Barry, J.C., Downing, K.F., Rajpar, A.R., and Raza, S.M. 2005. Will Downs and the Zinda Pir Dome. Palaeontologia Electronica, 8:1-19.

Lucas, S.G. and Emry, R.J., 1999. Taxonomy and biochronological significance of Paraentelodon, a giant entelodont (Mammalia, Artiodactyla) from the late Oligocene of Eurasia. Journal of Vertebrate Paleontology, 19:160-168.

Martinez, J.-N. and Sudre, J. 1995. The astragalus of Paleogene artiodactyls: comparative morphology, variability and prediction of body mass. Lethaia, 28:197-209.

Matthew, W.D. and Granger, W. 1924. New insectivores and Ruminants from the tertiary of Mongolia with remarks on the correlation. American Museum Novitates, 105:1-7.

Meijaard, E. and Groves, C.P. 2004. A taxonomic revision of the Tragulus mouse-deer (Artiodactyla). Zoological Journal of the Linnean Society, 140:63-102.

Mennecart, B. 2015. The European Ruminants during the "Microbunodon Event" (MP28, Latest Oligocene): Impact of Climate Changes and Faunal Event on the Ruminant Evolution. PloS one, 10(2):e0116830.

Mennecart, B., Becker, D., and Berger, J.-P. 2011. Iberomeryx minor (Mammalia, Artiodactyla) from the early Oligocene of Soulce (Canton Jura, NW Switzerland): systematics and palaeodiet. Swiss Journal of Geosciences, 104 (Suppl 1):115-132.

Métais, G., Antoine, P.-O., Marivaux, L., Welcomme, J.L., and Ducrocq, S. 2003. New artiodactyl ruminant (Mammalia) from the late Oligocene of Pakistan. Acta Palaeontologica Polonica, 48:375-382.

Métais, G., Chaimanee, Y., Jaeger, J.-J., and Ducrocq, S. 2001. New remains of primitive ruminants from Thailand: evidence of the early evolution of the Ruminantia in Asia. Zoologica Scripta, 30:231-249.

Métais, G., Chaimanee, Y., Jaeger, J.-J., and Ducrocq, S. 2007. Eocene bunoselenodont Artiodactyla from southern Thailand, and the early evolution of Ruminantia in South Asia. Naturwissenschaften, 94:493498.

Métais, G., Sen, S., Sözeri, K., Peigné, S., and Varol, B. 2015. Late Paleogene terrestrial fauna and paleoenvironments in Eastern Anatolia: New insights from the Kağızman-Tuzluca Basin. Journal of Asian Earth Sciences, 107:96-109. 
Métais, G., Welcomme, J.-L., and Ducrocq, S. 2009. Lophiomerycid ruminants from the Oligocene of the Bugti Hills (Balochistan, Pakistan). Journal of Vertebrate Paleontology, 29:1-12.

Métais, G. and Vislobokova, I.A. 2007. Basal Ruminants, pp. 189-212. In Prothero, D.R. and Foss, S.E. (eds.), The Evolution of Artiodactyls. The Johns Hopkins University Press, Baltimore.

Milne-Edwards, A. 1864. Recherches anatomiques, zoologiques, et paléontologiques sur la famille des chevrotains. Annales des Sciences Naturelles, Paris, 5:1-56.

Nikolov, I. and Heissig, K. 1985. Fossile Säugetiere aus dem Obereozän und Unteroligozän Bulgariens und ihre Bedeutung für die Palaogeographie. Mitteilungen des Bayerische Staatssammlung für Paläontologie und historische Geologie, 25:61-79.

Novello, A., Blondel, C., and Brunet, M. 2010. Feeding behavior and ecology of the late Oligocene Moschidae (Mammalia, Ruminantia) from La Milloque (France): Evidence from dental microwear analysis. Comptes Rendus Palevol, 9:471-478.

Pekar, S.F., DeConto, R.M., and Harwood, D.M. 2006. Resolving a late Oligocene conundrum: Deep-sea warming and Antarctic glaciation. Palaeogeography, Palaeoclimatology, Palaeoecology, 231:29-40.

Popov, S.V., Rögl, F., Rozanov, A.Y., Steininger, F.F., Shcherba, I.G., and Kovac, M. 2004. LithologicPaleogeographic maps of Paratethys. Courier Forschungsinstitut Senckenberg, 250:1-46.

Rössner, G.E. 2007. Family Tragulidae, p. 213-220. In Prothero, D.R. and Foss, S.E. (eds.), The Evolution of Artiodactyls. The Johns Hopkins University Press, Baltimore.

Russell, D.E. and Zhai, R.J. 1987. The Paleogene of Asia: mammals and stratigraphy. Mémoire $d u$ Museum Nationale d'Histoire Naturelle, 53:1-488.

Scherler, L., Mennecart, B., Hiard, F., and Becker, D. 2013. Evolutionary history of hoofed mammals during the Oligocene-Miocene transition in Western Europe. Swiss Journal of Geosciences, 106:349-369.

Scopoli, G.A. 1777. Introductio ad historiam naturalem sistens genera lapidum, plantarum et animalium hactenus detecta, caracteribus essentialibus donata, in tribus divisa, subinde ad leges naturae. Gerie, Prague.

Sen, S., Antoine, P.-O., Varol, B., Ayyildiz, T., and Sözeri, K. 2011. Giant rhinoceros Paraceratherium and other vertebrates from Oligocene and middle Miocene deposits of the Kağızman-Tuzluca Basin, Eastern Turkey. Naturwissenschaften, 98:407-423.

Sen, S., Seyitoglu, G., Karadenizli, L., Kazanci, N., Varol, B., and Araz, H. 1998. Mammalian biochronology of
Neogene depositis and its correlation with the lithostratigraphy in the Çankırı -Çorum basin, central Anatolia, Turkey. Eclogae Geologicae Helvetiae, 91:307-320.

Şengör, A.M.C. and Yilmaz, Y. 1981. Tethyan evolution of Turkey: a plate tectonic approach. Tectonophysics, 75:181-241.

Stehlin, H.G. 1909. Remarques sur les faunules de mammifères de l'Eocène et de l'Oligocène du Bassin de Paris. Bulletin de la Société Géologique de France, 4:488-520.

Sudre, J. 1984. Cryptomeryx (Schlosser 1886), Tragulidé de l'Oligocène d'Europe; Relation du genre et considération sur l'origine des ruminants. Palaeovertebrata, 14:1-22.

Sudre, J. 1995. Le Garouillas et les sites contemporains (Oligocène, MP 25) des phosphorites du Quercy (Lot, Tarn-et-Garonne, France) et leur faunes de vertébrés. Palaeontographica, 236:205-256.

Tong, Y., Zheng, S., and Qiu, Z. 1995. Cenozoic mammal ages of China. Vertebrata PalAsiatica, 33:290-314.

Trofimov, B.A. 1958. New Bovidae from the Oligocene of Central Asia. Vertebrata PalAsiatica 2:243-247.

Ünay, E., de Bruijn, H., and Saraç, G. 2003. The Oligocene rodent record of Anatolia: a review, p. 531-537. In Reumer, J.W.F. and Wessels, W. (eds.), Distribution and migration of Tertiary mammals in Eurasia. A volume in honour of Hans de Bruijn. DEINSEA, Rotterdam.

Varol, B., Sen, S., Ayyıldız, T., Sözeri, K., Karakas, Z., and Métais, G. 2015. Sedimentology and Stratigraphy of Cenozoic Deposits in the Kağızman-Tuzluca Basin, Northeastern Turkey. International Journal of Earth Sciences, 1-31.

Vislobokova, I.A. 2001. Evolution and classification of Tragulina (Ruminantia, Artiodactyla). Paleontological Journal, 35: 69-145.

Vislobokova, I.A. and Daxner-Höck, G. 2002. Oligoceneearly Miocene ruminants from the Valley of Lakes (Central Mongolia). Annalen des Naturhistorischen Museums in Wien, 103A:213-235.

Vislobokova, I.A., Dmitrieva, E.L., and Trofimov, B.A. 1996. Ruminants on the Paleogene-Neogene boundary in Mongolia. Palaeontological Journal, 30:99-108.

Webb, S.D. and Taylor, B.E. 1980. The phylogeny of hornless ruminants and a description of the cranium of Archaeomeryx. Bulletin of the American Museum of Natural History, 167:117-158.

Woodburne, M.O. 2006. Mammal Ages. Stratigraphy, 3:229-261.

Zachos, J.C., Sloan, L., Thomas, E., and Billups, K. 2001. Trends, rhythms, and aberrations in global climate 65 Ma to present. Science, 292:686-693. 